HID 42 (2015)

\title{
LA EXENCIÓN FISCAL, ENTRE PRIVILEGIO Y CONFLICTO: LOS EXCUSADOS DE LA IGLESIA EN ASTORGA, LEÓN Y OVIEDO (SIGLOS XIII-XIV) ${ }^{1}$
}

\author{
TAX EXEMPTION AS PRIVILEGE AND CONFLICT: \\ THE “EXCUSADOS” OF THE CHURCH IN ASTORGA, LEÓN AND \\ OVIEDO $\left(13^{\mathrm{TH}}-14^{\mathrm{TH}}\right.$ CENTURIES)
}

\author{
Raúl GonzÁlez GonzÁlez \\ Universidad de Oviedo \\ raull@telecable.es
}

RESUMEN: El objetivo de este artículo es ofrecer un acercamiento al estudio de las relaciones entre fiscalidad y poder en las sociedades urbanas de la Edad Media a través del análisis de un caso concreto de exención fiscal: la concedida a los excusados de la Iglesia. Para ello nos centraremos en el ejemplo de tres ciudades episcopales del norte peninsular (Astorga, León y Oviedo) a lo largo de los siglos XIII y XIV, analizando el origen y fundamentación de los privilegios de nombramiento de excusados, los conflictos que provocó dicha exención fiscal y la integración de los excusados de la Iglesia en la sociedad local.

Palabras ClaVE: excusados, fiscalidad, historia de la iglesia, sociedades urbanas, edad media.

ABSTRACT: The aim of this paper is to offer an aproach to the study of the interaction of taxation and power in medieval urban societies through the analysis of a particular case of tax exemption: the one granted to the "excusados" of the Church. With that purpose we will consider the example of three episcopal cities from Northern Spain (Astorga, León and Oviedo) throughout $13^{\text {th }}$ and $14^{\text {th }}$ centuries. We will analyze the origins and foundation of the privileges that granted the

1. Abreviaturas utilizadas: $\mathrm{ACO}=$ Archivo Capitular de Oviedo; $\mathrm{ACL}=$ Archivo de la Catedral de Léón. Este trabajo se ha desarrollado en el marco de una beca predoctoral del programa "Severo Ochoa" (ref. BP11-091), financiada por el Gobierno del Principado de Asturias a través de la FICYT. Además, se inscribe en el Proyecto de Investigación financiado por el Ministerio de Economía y Competitividad "Poder, sociedad y fiscalidad en el entorno geográfico de la Cornisa Cantábrica en el tránsito del Medievo a la Modernidad", HAR2011-27016-C02-01, con sede en la UPV/EHU. Pero, sobre todo, no hubiera sido posible sin las valiosas lecciones de mi directora, la profesora $\mathrm{M}^{\mathrm{a}}$ Soledad Beltrán Suárez, quien ya trabajó sobre el tema en su tesis doctoral y ofreció un acercamiento comparativo al mismo dentro de la asignatura "Poder episcopal, sociedad urbana y conflictos en la Corona de Castilla (ss. XI-XV)" del ya lamentablemente extinto programa de master "La ciudad medieval", de la Universidad de Oviedo. 
nomination of "excusados", the conflicts which were caused by such a tax exemption and the integration of the "excusados" of the Church in local society.

KEYWORDS: excusados, taxation, history of the church, urban societies, middle ages.

\section{INTRODUCCIÓN}

En los últimos años los trabajos sobre fiscalidad están alcanzando un desarrollo verdaderamente espectacular entre las investigaciones dedicadas a la Corona de Castilla en la Baja Edad Media, y el presente artículo no pretende ser más que una pequeña contribución a los intentos de enfocar dicho campo de estudio desde perspectivas afines a la historia social. Me ocuparé concretamente de un elemento tan importante en los sistemas fiscales medievales como es la noción de exención, que sirve como elemento diferenciador de una minoría privilegiada en el seno de la comunidad, reportándole al mismo tiempo un beneficio económico y una superioridad de estatus ${ }^{2}$. Lo haré a través del estudio de una figura específica, especialmente interesante por cuanto la integran personas que no son privilegiados natos: los "excusados de la Iglesia", es decir, individuos de condición originalmente pechera que adquieren el privilegio de exención por haber sido señalados por la autoridad eclesiástica para gozar de unos privilegios de inmunidad fiscal que en principio sólo corresponderían al clero. El presente trabajo pretender contribuir con ello a rellenar una cierta laguna historiográfica, pues esta modalidad de exención ha recibido una atención muy escasa por parte del medievalismo peninsular, careciendo prácticamente hasta la fecha de estudios específicos ${ }^{3}$.

2. M.I. del Val Valdivieso, "Oligarquía versus común (Consecuencias sociopolíticas del triunfo del Regimiento en las ciudades castellanas)”, Medievalismo: Boletín de la Sociedad Española de Estudios Medievales, 4 (1994), pp. 49-52. No obstante, como señaló uno de los evaluadores anónimos del artículo, y aunque pueda parecer una obviedad, no debe olvidarse que la exención afectó también a los sectores más desfavorecidos de la sociedad, cuya pobreza les impedía hacer frente a las cargas tributarias. Lo señala, por ejemplo, J.D. González Arce, "Los precedentes de la fiscalidad extraordinaria de la monarquía hispana: los pedidos reales en la Castilla al sur del Tajo (siglos XIV y XV)", en A. Collantes de Terán Sánchez (ed.), Fuentes para el estudio del negocio fiscal y financiero en los reinos hispánicos (siglos XIV-XVI), Madrid, 2010, pp. 13-4.

3. Si bien existen alusiones más o menos de pasada a la figura de los excusados de la Iglesia en algunos estudios dedicados a cuestiones más generales, que aun en el mejor de los casos no suelen dedicarle más de unas pocas páginas (cuando no un par de líneas): M.A. Ladero Quesada, La Hacienda Real de Castilla en el siglo XV, La Laguna, 1973, p. 210; D. Menjot, "L'incidence sociale de la fiscalité directe des Trastamares de Castille au XIV siècle", Historia. Instituciones. Documentos, 5 (1978), pp. 348-9; J. M. Nieto Soria, Iglesia y poder real en Castilla. El episcopado (1250-1350), Madrid, 1988, pp. 170-1; A. Arranz Guzmán, "Los enfrentamientos entre concejos y poderes eclesiásticos en las cortes castellanas: ¿sincronización de los conflictos?”, Hispania, 171 (1989), pp. 6, 10n, 30-1, 43 y 63; M.A. Ladero Quesada, Fiscalidad y poder real en Castilla (1252-1369), Madrid, 1993, p. 268; J.M. Nieto Soria, Iglesia y génesis del Estado moderno en Castilla (1369-1480), Madrid, 1993, pp. 100-1; M.A. Ladero Quesada, "Las haciendas concejiles en la Corona de Castilla (una visión de conjunto)", en Finanzas y fiscalidad municipal (V Congreso de Estudios Medievales), Ávila, 1997, p. 16; A. Arranz Guzmán, "Clérigos y laicos en las cortes castellano-leonesas: la conflictividad como hilo conductor", en El reino de León en la Alta Edad 
Mi ámbito de estudio serán las tres ciudades episcopales asturleonesas: Astorga, León y Oviedo, dentro de un marco cronológico centrado en los siglos XIII-

Media, IX, León, 1997, pp. 638-647; A. Arranz Guzmán, "Pedro I ante los enfrentamientos entre concejos y prelados castellanos", Anuario de Estudios Medievales, 30/1 (2000), pp. 239-240, 243, 255n, 266 y 275; J.M. Nieto Soria y J. Díaz Ibáñez, "Élites y Clientelas Eclesiásticas (siglos XIII al XV): propuestas metodológicas desde el caso castellano", en F. Themudo Barata (ed.), Elites e redes clientelares na Idade Média, Lisboa, 2001, p. 128; J.I. Ruiz de la Peña Solar, "Las ciudades de señorío eclesiástico y los conflictos por el control del gobierno local (1252-1350)", en J.I. de la Iglesia Duarte (coord.), Conflictos sociales, políticos e intelectuales en la España de los siglos XIV y XV. XIV Semana de Estudios Medievales, Nájera 2003, Logroño, 2004, pp. 131-3. Sin duda, los únicos excusados de la Iglesia que han recibido una cierta atención historiográfica sostenida en el tiempo son los de la catedral de Palencia, si bien, más que objeto de estudio en sí mismo, aparecen mencionados en diversos trabajos como un aspecto más de los conflictos entre la iglesia palentina y el concejo: R. Carande, "El obispo, el concejo y los regidores de Palencia (1352-1422). Aportación documental sobre el gobierno de una ciudad en la Edad Media", en Siete estudios de Historia de España, Barcelona, 1969, pp. 62-3 y 81-2; J.M. Nieto Soria, "La relación de poderes en un señorío eclesiástico de ámbito urbano: Palencia, 1280-1305”, en La ciudad hispánica durante los siglos XIII a XVI, I, Madrid, 1985, p. 628; S. Francia Lorenzo, "El cabildo palentino en el siglo XV", Publicaciones de la Institución Tello Téllez de Meneses, 59 (1988), pp. 154-8; A. Esteban Recio, Palencia a fines de la Edad Media. Una ciudad de señorio episcopal, Valladolid, 1989, pp. 156-7, 159, 163, 168-9 y 171-2; M.J. Fuente Pérez, La ciudad de Palencia en el siglo XV. Aportación al estudio de las ciudades castellanas en la Baja Edad Media, Madrid, 1989, pp. 36-7 y 459 (y passim en el apartado dedicado a los conflictos de los siglos XII-XIV, pp. 54-73); J.I. Coria Colino, "La ciudad de Palencia de finales del siglo XII hasta la mitad del siglo XIII: organización municipal”, en C. Aniz Iriarte y L.V. Díaz Martín (coords.), Santo Domingo de Caleruega: contexto cultural. III Jornadas de Estudios Medievales, Salamanca, 1995, pp. 173, 221-2 y 229-231; A. Cabeza Rodríguez, "Grupos excluidos y formas de asimilación y reproducción social. El ejemplo de la catedral de Palencia en la época moderna", en J. Hernández Franco (ed.), Familia y poder. Sistemas de reproducción social en España (siglos XVI-XVIII), Murcia, 1995, pp. 105 y 120; C. Reglero de la Fuente, "La iglesia catedral de Palencia en el siglo XIV (1313-1397): crisis y reformas", Edad Media. Revista de Historia, 7 (2005-2006), pp. 124-6 y 155. La excepción es el excelente trabajo de A. Polanco Pérez, La catedral de Palencia en el siglo XV (1402-1470). Poder y comportamientos sociales a finales de la Edad Media, Palencia, 2008, pp. 221-230, en el que se profundiza en la realidad social de los excusados en el siglo XV. Además de los trabajos sobre Astorga, León u Oviedo que se citarán a lo largo del presente artículo, pueden encontrarse alusiones a esta figura para otros ámbitos de la Corona de Castilla en J. Gautier Dalché, Historia urbana de León y Castilla en la Edad Media (siglos IX-XIII), Madrid, 1979, pp. 284-285 (sobre los casos de Sahagún y Orense); J.M. Monsalvo Antón, El sistema político concejil. El ejemplo del señorío medieval de Alba de Tormes y su concejo de villa y tierra, Salamanca, 1988, p. 393, nota 100; M. Santamaría Lancho, "El cabildo catedralicio de Segovia como aparato de poder en el sistema político urbano durante el siglo XV", Studia Historica. Historia Medieval, 8 (1990), pp. 49 y 52; M. Rodríguez Llopis e I. García Díaz, Iglesia y sociedad feudal: el Cabildo de la Catedral de Murcia en la Baja Edad Media, Murcia, 1994, pp. 50-1; J. Díaz Ibáñez, "Monarquía y conflictos Iglesia-concejos en la Castilla bajomedieval. El caso del obispado de Cuenca (1280-1406)", En la España Medieval, 17 (1994), pp. 46-7; J.M. Monsalvo Antón, "Gobierno municipal, poderes urbanos y toma de decisiones en los concejos castellanos bajomedievales (consideraciones a partir de concejos salmantinos y abulenses)", en Las sociedades urbanas en la España medieval. XXIX Semana de Estudios Medievales (Estella, 15-19 julio 2002), Pamplona, 2003, p. 465, nota 79 (sobre el caso de Ávila); E. Cal Pardo, Episcopologio Mindoniense, Santiago de Compostela, 2003, pp. 182-3; o J. Díaz Ibáñez, Iglesia, sociedad y poder en Castilla. El obispado de Cuenca en la Edad Media (siglos XII-XV), Cuenca, 2003, pp. 218, 220, 372-3, 436 y 570; mientras que, para la Corona de Aragón, P. Verdés-Pijuan, "La contribución eclesiástica a la fiscalidad municipal en Cataluña durante la época bajomedieval", en J. Morelló Baget (ed.), Financiar el reino terrenal: la contribución de la Iglesia a finales de la Edad Media (siglos XIII-XVI), Barcelona, 2013, p. 152, señala la voluntad de los clérigos de extender la exención eclesiástica a sus domésticos y familiares. Debo agradecer las sugerencias bibliográficas de Albert Reixach Sala (CSIC - Institució Milà i Fontanals), Beatriz Majo Tomé (Universidad de Valladolid) y Esther Tello Hernández (CSIC - Institució Milà i Fontanals). 
XIV. Dado que el elemento que imprime un sello particular a los tres núcleos es el hecho de haber sido lugares de señorío compartido, en los que el obispo ejerció diversas facultades jurisdiccionales ${ }^{4}$, sólo me ocuparé de los excusados de las iglesias catedralicias (vinculados al obispo o al cabildo), aunque existieron evidentemente también otros excusados, tanto de instituciones eclesiásticas como de laicos 5 .

A fin de clarificar el análisis posterior, propongo la siguiente tipología de los excusados de la Iglesia que se encontrarán a lo largo del trabajo:

En primer lugar se encuentran los que podrían considerarse los excusados más genuinos: aquellos cuya exención no va asociada al desempeño de una tarea concreta, sino que son libremente designados por el obispo y el clero capitular de entre los habitantes de la ciudad. Para diferenciarlos de los otros, les daremos el nombre de excusados "de servicio", pues, al menos en teoría, esta figura está pensada para que los eclesiásticos sustraigan del fisco a sus domésticos y clientes, función originaria que no parece haber sido respetada con demasiado rigor, como veremos más adelante.

Por otro lado, están los excusados vinculados al trabajo en la construcción de la catedral, a los que ya las propias fuentes denominan "excusados de la obra".

Finalmente, existe un tipo de excusados cuya condición está ligada al cometido de proveer de carne o pescado al personal eclesiástico en establecimientos específicos. Me referiré a ellos como excusados "de abastecimiento".

\section{ORÍGENES Y FUNDAMENTACIÓN DE LOS PRIVILEGIOS DE EXCUSADOS}

Para una correcta comprensión de la naturaleza de estos excusados de la Iglesia es necesario analizar el proceso a través del cual el clero catedralicio logró que los reyes le concedieran o reconocieran el privilegio de nominación de exentos fiscales. Ahora bien, dado que los diversos tipos de excusados que hemos señalado en el apartado anterior son el fruto de desarrollos también diferentes, sus orígenes y fundamentación se analizarán por separado.

4. Ruiz de la Peña Solar, "Las ciudades de señorío eclesiástico...", op. cit., pp. 125-6 y passim. Conviene señalar que en León el juez de la Iglesia fue suprimido por Fernando IV en 1304: J.I. Coria Colino, "La eliminación de los jueces de la Iglesia en los concejos medievales de la Corona de Castilla (s. XIII-XIV: León, Zamora, Salamanca y Murcia)", en Medievo hispano: estudios in memoriam del Prof. Derek W. Lomax, Madrid, 1995, p. 118.

5. Sobre los excusados en general, vid. A. Romero Martínez, Fisco y recaudación. Impuestos directos y sistemas de cobro en la Castilla medieval, Granada, 1999, pp. 42-5. De las tres ciudades objeto del presente estudio, la variedad de excusados está especialmente bien documentada para León, donde en los siglos XIII-XIV encontramos menciones a excusados de la colegiata de San Isidoro, los caballeros, las órdenes, los frailes predicadores, el Adelantado Mayor de León y Asturias o los ballesteros del rey: J. Rodríguez Fernández, "El señorío isidoriano de Renueva (León)”, Archivos Leoneses. Revista de estudios y documentación de los reinos hispano-occidentales, 55-56 (1974), doc. nº 6, pp. 245-6; J.A. Martín Fuertes, Colección documental del Archivo Municipal de León (1219-1400), León, 1998, docs. $\mathrm{n}^{\circ} 3$, pp. $5-7, \mathrm{n}^{\circ} 12$, p. 29 , no 25 , p. $43, \mathrm{n}^{\circ} 200$, pp. 275-6 y n⿳2 232 , pp. 318-320, respectivamente. 


\subsection{Excusados "de servicio"}

Los orígenes de esta figura son oscuros, pues se basan muy probablemente en costumbres locales que sólo afloran tardíamente en la documentación, una vez que obtienen la explícita sanción regia. Como ocurre con el espinoso asunto de la fundamentación de los poderes jurisdiccionales del obispo sobre la ciudad ${ }^{6}$, cuando contamos con privilegios reales de concesión de la facultad de nombramiento de excusados me inclinaría por ver en ellos menos un punto de partida que el fruto de una negociación en torno a realidades o pretensiones previas que el poder monárquico está tratando de formalizar, legitimar o incluso limitar (al fijar por ejemplo un número concreto de excusados). Algo nos están diciendo, por tanto, sobre el proceso de afirmación de una fiscalidad regia que tiene la necesidad de reconocer la existencia de esas realidades o pretensiones precisamente en el momento en el que puede empezar a entrar en conflicto con ellas.

Si pasamos del punto de vista de la monarquía al de las iglesias catedralicias, habría que entender seguramente la figura de los excusados "de servicio" como una suerte de apéndice necesario a la inmunidad eclesiástica, principio que no afectaría sólo a la persona de los clérigos, sino que se extendería también a su domicilio y al conjunto de domésticos que lo habitan ${ }^{7}$ : servidores, familiares, clientes, criados... Desde esta perspectiva, en origen la exención fiscal de los domésticos del clero capitular no se fundamentaría en un privilegio individual, sino que sería meramente la consecuencia lógica de la inmunidad de que gozaban las “casas" (en sentido físico y social) de los eclesiásticos ${ }^{8}$. Dado que una exención de orden tan general debió de ser fácilmente aprovechada para generar abusos diversos, haciendo pasar por domésticos del clero a todo tipo de vecinos interesados en evadir el pago de tributos, el poder monárquico habría acabado optando por fijar el alcance de la misma a un número concreto de individuos: los "excusados". Este intento de clarificación fiscal pudo tener mucho de resignación ante una realidad difícil de erradicar: si no podía evitarse el fraude, al menos en adelante sólo podría beneficiarse de él un número limitado de personas.

6. Para el caso ovetense, y como modelo metodológico, es de consulta obligada J.I. Ruiz de la Peña Solar, S. Beltrán Suárez, "Los orígenes del poder episcopal sobre la ciudad de Oviedo en la Edad Media”, En la España Medieval, 30 (2007), pp. 65-90.

7. Grupo social analizado para el Oviedo medieval en S. Suárez Beltrán, "Clientelas domésticas en Oviedo durante la Edad Media (siglos XIII-XV)”, Asturiensia Medievalia, 8 (1995-1996), pp. 341-359.

8. Para León contamos con privilegios reales explícitos acerca de la inviolabilidad del domicilio de los canónigos. En 1098 Alfonso VI exime a los canónigos de Santa María de Regla de todo tributo regio y establece que "nullus maiorinus vel sagio vel alius homo intret in casas canonicorum pro aliqua calupnia vel pro alia causa" (J.M. Ruiz Asencio, Colección documental del Archivo de la Catedral de León, IV (1032-1109), León, 1990, doc. $\mathrm{n}^{\circ}$ 1297), y en 1141 Alfonso VII les otorga de nuevo un privilegio en el que se les excusa de todo pago al fisco, ordenando que "sagio nec alcaide vel aliquis homo in vestras domos non intret per ulla calumpnia, neque inde aliquid abstraat ui”. Aunque la similitud de ambos diplomas hace sospechar, sobre todo si tenemos en cuenta que el segundo no menciona al primero, y que éste se ha conservado en copia de mediados del siglo XII, no me consta que existan dudas en torno a la autenticidad del texto. 
El proceso parece relativamente claro para los obispos, que ya en época temprana lograron obtener privilegios explícitos de los reyes en este sentido. El caso más precoz es el de León, pues ya en 1098 Alfonso VI concede al obispo 12 excusados "de hominibus suis qui ei serviunt", aclarando que están exentos "de foro et pecto et fosado et qualibet exaccione regis" 10 ; mientras que para las otras dos ciudades de mi interés hay que esperar al reinado de Alfonso IX, que en 1188 exime "de pecto, petito et de tota alia fazendaria et regio fisco" a "totam clientelam de casa Ovetensis episcopi" "11 (en fecha desconocida el número se limitó a 15 excusados, como veremos) y en 1229 reconoce, tras efectuar una pesquisa al respecto, que al obispo de Astorga le corresponden 22 excusados, ordenando eso sí "que de melioribus omnes non excuset", en velada alusión a la posibilidad de fraude ${ }^{12}$.

Más problemática es la pretensión que tuvo el clero capitular de disfrutar de la misma facultad de nombrar excusados, pues, más allá de las referencias ya señaladas a la inmunidad de las casas de los canónigos leoneses ${ }^{13}$, carecemos del tipo de privilegios explícitos y tempranos que existen para los obispos. De hecho, para los capitulares de Astorga no encontramos mención alguna a privilegios o pretensiones de esta naturaleza hasta fecha tan tardía como 1312, cuando Fernando IV, en un diploma hoy perdido ${ }^{14}$, concedía la exención de tributos reales a los paniaguados y criados del deán y cabildo ${ }^{15}$.

9. Ruiz Asencio, Colección documental... IV, op. cit., doc. $\mathrm{n}^{\circ}$ 1297. Se trata del documento citado en la nota anterior. A las sospechas ya señaladas cabría añadir la excesiva precocidad de la concesión de excusados episcopales y el hecho de que sabemos que en 1153 Alfonso VII restituía a San Isidoro de León el derecho antiguo de nombrar precisamente 12 excusados en la ciudad: Rodríguez Fernández, "El señorío isidoriano...", op. cit., doc. n ${ }^{\circ}$ 1, pp. 240-1. Que la supuesta copia de mediados del siglo XII del privilegio de 1098 a la catedral leonesa no sea en realidad sino una refacción interesada del privilegio del Emperador de 1141, la cual, dándole un aire antiguo y trasladando su tenor a época de Alfonso VI, pretendía incorporar a la mitra el privilegio de los 12 excusados concedido o reconocido a San Isidoro en 1153, es una mera hipótesis cuya ratificación o refutación requeriría de destrezas lingüísticas y diplomáticas de las que carezco.

10. Íd. En 1284 un documento de Sancho IV hace referencia a que los obispos de León "ovieron siempre doçe veçinos vuestros, de y de la villa, escussados de uueste e de todo otro pecho, salvo de moneda forera": J.M. Ruiz Asencio, J. A. Martín Fuertes, Colección documental del Archivo de la Catedral de León, IX (1269-1300), León, 1994, doc. nº 2440.

11. S. García Larragueta, Colección de documentos de la catedral de Oviedo, Oviedo, 1962, doc. $\mathrm{n}^{\mathrm{o}} 210$, pp. 500-501.

12. G. Cavero Domínguez, C. Álvarez Álvarez, J.A. Martín Fuertes, Colección documental del Archivo Diocesano de Astorga, León, 2001, doc. n 49, pp. 86-7.

13. Vid. nota 8. Además, un documento falso, pretendidamente de 1087 y atribuido a Alfonso VI, exime de todo tributo regio o episcopal a los clérigos de la catedral de Astorga y ordena "ut scurro fici cuiuslibet non sit ausus introire vestris domibus ullis diebus ullisque temporibus pro nulla calumnia": G. Cavero Domínguez, E. Martín López, Colección documental de la catedral de Astorga, I (646-1126), León, 1999, doc. $\mathrm{n}^{\circ}$ 448, pp. 350-3.

14. Es bien conocida la penuria de la documentación catedralicia de Astorga que ha llegado a nuestros días, debido al incendio del archivo por los ingleses en 1814 durante la Guerra de Independencia, lo que obliga a recurrir sistemáticamente a los regestos recogidos en inventarios de la Edad Moderna: Cavero Domínguez, Martín López, Colección documental... I, op. cit., pp. 13-20.

15. G. Cavero Domínguez, S. Domínguez Sánchez, Colección documental de la catedral de Astorga, III (1300-1499), León, 2000, doc. n 1591, p. 107. En 1378 el juez real en Astorga, al sentenciar que los canónigos, sus familiares y criados no deben pagar el tributo de la moneda, se refiere 
El caso del cabildo leonés es el más enigmático, pues no contamos con un solo documento regio que conceda al clero capitular el derecho de nombrar excusados "de servicio", pero gracias a los sucesivos pleitos de la Iglesia con el concejo de León sabemos que los canónigos ejercían dicha facultad al menos desde mediados del siglo XIII: ya en 1241 el concejo se queja a Fernando III de que "el obispo e sos canóligos tomavan escusados quales non devien", y el rey ordena hacer pesquisa acerca de cuál era el número y características de tales excusados en época de Alfonso $\mathrm{IX}^{16}$. Por desgracia, desconocemos el resultado de las indagaciones, pero lo que parece estar en cuestión no es tanto la propia facultad de designar excusados como el ejercicio abusivo de la misma. De todos modos, parece seguro que el cabildo leonés nunca tuvo un privilegio explícito de concesión de excusados por parte de la monarquía y que basó sus pretensiones fundamentalmente en el viejo privilegio de inmunidad de sus domicilios, tal y como vemos con claridad en una relación de agravios que el obispo y cabildo dicen haber sufrido del concejo, presentada en torno al año 1270. En ella se quejan, entre otras cosas, de que las autoridades municipales han prendado contra derecho a los vasallos, criados y excusados de la Iglesia, "quebrantando las casas de los canóligos e levando ende los pennos", y el único privilegio real que alegan en su favor es precisamente el relativo a "que ningún juyz o sayón o otro homne qualquier de so senorío non entre en casa de canóligo por fazer nenguna prinda"17.

Finalmente, para el cabildo ovetense estamos mejor informados. Aunque no se han conservado los documentos originales, en 1268 una sentencia de Alfonso $\mathrm{X}$ parece reconocer la validez de un privilegio de Alfonso IX que había sido presentado ante la justicia regia por el procurador de la iglesia de Oviedo, según el cual los hombres del obispo y el cabildo "eran escusados de todo pecho e de toda fazendera" "18; y en 1355 Pedro I asegura que precisamente Alfonso X había ordenado que el obispo y cabildo de Oviedo tuviesen sus excusados tal y como los habían tenido en tiempos de Alfonso IX y Fernando III ${ }^{19}$. Y lo cierto es que la facultad de nombramiento de excusados por el clero capitular ovetense parece haber estado estipulada de manera especialmente clara, porque ha llegado hasta nosotros una lista elaborada en 1301 que recoge exactamente quiénes son en ese momento los excusados del obispo y del cabildo ${ }^{20}$. Sabemos así que al obispo le correspondían 15 excusados, al deán 6, 4 al resto de dignidades capitulares (arcedianos, tesorero y maestrescuela) y 2 a cada uno de los 38 canónigos y 22 racione-

al privilegio que les exonera como "antiguo": Cavero Domínguez, Domínguez Sánchez, Colección documental... III, op. cit., doc. $\mathrm{n}^{\mathrm{o}} 1820$, p. 281.

16. J.M. Ruiz Asencio, Colección documental del Archivo de la Catedral de León, VIII (12301269), León, 1993, doc. nº 2041.

17. Ruiz Asencio, Martín Fuertes, Colección documental... IX, op. cit., doc. no 2296.

18. C. Miguel Vigil, Colección histórico-diplomática del Ayuntamiento de Oviedo, Oviedo, 1991, doc. ${ }^{\text {o }}$ XXXIII, p. 60. No entro en los detalles del pleito, que veremos más adelante.

19. Documento $\mathrm{n}^{\circ} 3$ del Apéndice Documental.

20. Documento $\mathrm{n}^{\circ} 1$ del Apéndice Documental. 
ros, mientras que los 6 oficiales del cabildo son también excusados ellos mismos ${ }^{21}$; cifras que coinciden exactamente con el resultado de una pesquisa ordenada por Pedro I a mediados del siglo $\mathrm{XIV}^{22}$. Es decir, la iglesia ovetense garantizaba la exención fiscal de 187 individuos, cantidad nada insignificante para una ciudad que contaba en época de Alfonso X con 900 vecinos $^{23}$.

\subsection{Excusados de la obra}

Cuestión muy diferente son los excusados de la obra, cuya fundamentación jurídica cuenta generalmente con privilegios nítidos, otorgados expresamente por los reyes para ese fin. Así, en 1277 Alfonso X concede al cabildo de la iglesia de León que 22 de los trabajadores en la obra de la catedral queden exentos "de todo pecho e de todo pedido e de fonssado e de fonssadera e del serviçio" 24 . Ahora bien, dado que el privilegio alfonsí especificaba los oficios que debían desempeñar tales excusados, concretamente "veynte pedreros e un vidriero e un ferrero", en 1290 la iglesia leonesa solicita a Sancho IV facultad para poder tomar los 22 excusados de entre cualquier menestral de la obra, independientemente de su profesión, de modo que el rey les concede que puedan sustituir "estos veynte pedreros e el vidriero e el ferrero o alguno dellos en otros atantos menesteriales que ellos vieren que les más cumple para la obra de su eglesia"25. La excesiva laxitud con la que el cabildo parece haber interpretado esta facultad de libre designación de los ex-

21. F.J. Fernández Conde, La clerecía ovetense en la Baja Edad Media. Estudio socioeconómico, Oviedo, 1982, p. 17; S. Suárez Beltrán, El cabildo de la catedral de Oviedo en la Edad Media, Oviedo, 1986, p. 55.

22. Documento $n^{\circ} 3$ del Apéndice Documental.

23. El dato procede de la noticia recogida en el inventario de documentación municipal elaborado en 1536, que nos informa de que se conservaban por entonces en el archivo del consistorio dos nóminas de vecinos elaboradas en 1269 para el repartimiento de 2.000 maravedís prestados al rey, según las cuales "tenía entonces la ciudad nuevecientos vecinos, sin el concejo" [es decir, sin incluir a los habitantes del alfoz] (Miguel Vigil, Colección... op. cit., p. 292, doc. $\mathrm{n}^{\circ}$ 13). El profesor Ruiz de la Peña ha calculado a partir de este dato, y teniendo en cuenta diversos factores, una población de unos 5.000 habitantes: J.I. Ruiz de la Peña Solar, Historia de Asturias, 5: Baja Edad Media, Salinas, 1979, pp. 101-2.

24. Ruiz Asencio, Martín Fuertes, Colección documental... IX, op. cit., doc. no 2378. Sabemos no obstante que el cabildo leonés tenía pretensiones en este sentido con anterioridad a la concesión del privilegio real, pues ya en torno a 1270 se queja de que el concejo había tomado prendas indebidamente, entrando en las casas "de los canóligos commo de los criados, commo de los escusados de la igrisia e commo de los pedreros de la obra de la igrisia, pero que non eran de so judgado e eran privilegiados de non dar con el concejo en ninguna taia e en ningún pedido e en ninguna renda del rey": Ruiz Asencio, Martín Fuertes, Colección documental... IX, op. cit., doc. n 2296 . En 1269 el concejo se había quejado precisamente de que "elos pedreros de la yglesia non pechavan con el conceyo, pero que non avíen privilegio porque se escusassen de dar en pecho", accediendo la Iglesia a "que pechassen con el conceyo elos pedreros que non mostrassen carta del rey porque fuessen escusados de pecho": Ruiz Asencio, Colección documental... VIII, op. cit., doc. $\mathrm{n}^{\circ}$ 2283. Por tanto, en 1277 Alfonso X está más bien reconociendo una exención previa, limitándola a un número concreto de trabajadores, que otorgando un privilegio radicalmente nuevo: J.M. Nieto Soria, "Los obispos de la diócesis de León en sus relaciones con la monarquía, 1250-1350”, Archivos Leoneses. Revista de estudios y documentación de los reinos hispano-occidentales, 74 (1983), pp. 214-5.

25. Ruiz Asencio, Martín Fuertes, Colección documental... IX, op. cit., doc. no 2543. 
cusados de la obra será en su momento motivo de conflicto con los recaudadores reales, como veremos más adelante.

Por desgracia, en Astorga carecemos de información alguna acerca del privilegio original de concesión. La primera noticia al respecto data del año 1374, cuando Enrique II ordena al concejo de dicha ciudad que respete la antigua exención de impuestos para los excusados de la obra de la catedral, como en épocas pasadas ${ }^{26}$.

La iglesia ovetense será la última de las tres sedes en obtener este tipo de privilegio, pues no será hasta 1388 que Juan I le concede 10 excusados para la obra de la catedral, hasta que finalice la construcción de la misma, "que sean canteros e obreros que labran e labraren en la obra de la dicha iglesia", exentos del pago de todo tributo regio, salvo alcabalas ${ }^{27}$. En la concesión parece haber jugado un papel fundamental la estrecha relación del obispo Gutierre de Toledo con el monarca, de quien fue eficaz agente en Asturias durante las rebeliones del conde de Noreña ${ }^{28}$.

De todos modos, parece que el factor principal para el otorgamiento del privilegio de excusados de la obra haya sido precisamente el desarrollo de las propias tareas de construcción de las grandes catedrales góticas, que arrancan con fuerza en León durante el episcopado de Martín Fernández (1254-1289) ${ }^{29}$ y en Oviedo con el de Gutierre de Toledo (1377-1389) ${ }^{30}$, precisamente los prelados que obtuvieron de los reyes la concesión de dicho privilegio para sus iglesias ${ }^{31}$.

\subsection{Excusados "de abastecimiento"}

El último tipo de privilegio de excusados data en los dos casos conocidos (la iglesia ovetense no parece haber contado con él ${ }^{32}$ ) de época de Fernando IV, que

26. Cavero Domínguez, Domínguez Sánchez, Colección documental... III, op. cit., doc. nº 1807, p. 275. En la nota 15 hemos visto que en esta época un privilegio "antiguo" puede datar de hace menos de 70 años, por lo que resulta imposible aventurar una fecha para la concesión original de estos excusados de la obra.

27. F. de Caso Fernández, Colección documental sobre la catedral de Oviedo, I (1300-1520), Gijón, 1982, doc. $\mathrm{n}^{\circ}$ 5, pp. 9-11.

28. F. de Caso Fernández, La construcción de la catedral de Oviedo (1293-1587), Oviedo, 1981, p. 165; F.J. Fernández Conde, Gutierre de Toledo, obispo de Oviedo (1377.1389). Reforma eclesiástica en la Asturias bajomedieval, Oviedo, 1978, pp. 97-122 y 253.

29. Aunque la fecha exacta de inicio de las obras de la catedral leonesa es objeto de debate, aún los partidarios de una cronología más temprana parecen reconocer que es bajo el episcopado de Martín Fernández cuando la construcción del templo gótico cobra un impulso definitivo, tras una serie de interrupciones y titubeos: H. Karge, "La arquitectura de la catedral de León en el contexto del gótico europeo”, en J. Yarza Luaces, M.V. Herráez Ortega, G. Boto Varela (eds.), La catedral de León en la Edad Media, León, 2004, pp. 113-144; M.V. Herráez Ortega, "La construcción del templo gótico", en id., pp. 145-176.

30. Caso Fernández, La construcción... op. cit., pp. 161-169.

31. Para Astorga estamos mucho peor informados, pero parece que en el siglo XIII aún se estaba concluyendo la catedral románica, y las obras de la gótica no se iniciaron hasta el último tercio del siglo XV: B. Velado Graña, La catedral de Astorga y su museo. Guía, Astorga, 1991, pp. 12-20.

32. Sabemos que en el siglo XVI tenía su propio carnicero, aunque no hay constancia de que tuviese condición de excusado. Así por ejemplo, en fecha indeterminada de dicha centuria el carnicero Juan del Coto, vecino de Oviedo, manifiesta en una carta enviada al cabildo "que por mandado de vuestras merçedes yo tengo cargo de la carneszería de vuestras merçedes y de probeer de todas las car- 
lo concede en 1302 a la iglesia de Astorga $^{33}$ y en 1311 a la de León ${ }^{34}$. En ambos casos el rey permite que tengan una carnicería exenta de la jurisdicción del concejo $^{35}$, en la que otorga que pongan 6 excusados (4 carniceros y 2 pescaderos) que les abastezcan de carne y pescado, los cuales estarán exentos de todo tributo real, salvo de moneda forera ${ }^{36}$.

\section{LA EXENCIÓN CUESTIONADA: CONFLICTOS EN TORNO A LOS EXCUSADOS}

En este apartado se prestará atención a los enfrentamientos que surgieron sobre los excusados de la Iglesia en Astorga, León y Oviedo durante los siglos XIII-XIV, con una contestación activa y prolongada en el tiempo por parte de los concejos y mucho más puntual por parte de los monarcas y agentes del fisco regio.

\subsection{Conflictos con los concejos}

En el siglo XIII los concejos de la Corona de Castilla alcanzan su madurez institucional, consolidándose las haciendas municipales ${ }^{37}$. Como consecuencia, en las

nes de baca y carnero que son neszesarias de se probeer para la gobernaçión e provimiento de vuestras merçedes" (ACO, Papel suelto grande, caja 213).

33. Cavero Domínguez, Domínguez Sánchez, Colección documental... III, op. cit., doc. nº 1534, pp. 69-70. De forma significativa, en 1380 Juan I ya se refiere a este privilegio como "inmemorial": Colección documental... III, op. cit., doc. $\mathrm{n}^{\circ} 1828$, p. 287.

34. J.A. Martín Fuertes, Colección documental del Archivo de la Catedral de León, XI (13011350), León, 1995, doc. n 2833, pp. 181-3.

35. Mientras que en el caso de la iglesia leonesa Fernando IV les da poder para construir la carnicería en el lugar de la ciudad que prefieran, para Astorga el rey especifica que se trata de la carnicería que ya les había dado Sancho IV en la plaza de San Martín. No parecen existir menciones a esta merced del rey Sancho ni siquiera en los regestos de la Edad Moderna, pero sí que tenemos constancia de que ya Fernando II había donado una carnicería a la iglesia asturicense, con 6 bancos de carnicería y pescadería, en lo que podría ser un precedente del privilegio concedido en 1302: G. Cavero Domínguez, E. Martín López, Colección documental de la catedral de Astorga, II (1126-1299), León, 2000, docs. $\mathrm{n}^{\circ} 772, \mathrm{n}^{\circ} 803$ y n $^{\circ} 804$, pp. $130-1$ y 152 .

36. Cavero Domínguez, Domínguez Sánchez, Colección documental... III, op. cit., doc. nº 1534 , p. 70 .

37. Ladero Quesada, Fiscalidad y poder real... op. cit., p. 303; A. Collantes de Terán, D. Menjot, "Hacienda y fiscalidad concejiles en la Corona de Castilla en la Edad Media", Historia. Instituciones. Documentos, 23 (1996), p. 219; D. Menjot, A. Collantes de Terán, "La génesis de la fiscalidad municipal en Castilla: primeros enfoques", Revista d'Història Medieval, 7 (1996), pp. 61-72; Ladero Quesada, "Las haciendas concejiles en la Corona de Castilla...", op. cit., pp. 11-12; Y. Guerrero Navarrete, "La fiscalidad como espacio privilegiado de construcción político identitaria urbana: Burgos en la Baja Edad Media”, Studia Historica. Historia Medieval, 30 (2012), p. 49. Para la consolidación y estructuración de la hacienda del concejo ovetense en el siglo XIII, véase J.I. Ruiz de la Peña Solar, "Las haciendas concejiles en el norte de la Península: el ejemplo ovetense", en Finanzas y fiscalidad municipal (V Congreso de Estudios Medievales), Ávila, 1997, pp. 507-552. En el caso de León, pueden hallarse algunas notas sobre la fiscalidad municipal en C. Estepa Díez, Estructura social de la ciudad de León (siglos XI-XIII), León, 1977, pp. 464-8, y, para una época más tardía, J.M. Santamarta Luengos, Señorio y relaciones de poder en León en la Baja Edad Media (Concejo y Cabildo Catedral en el siglo $X V$ ), León, 1993, pp. 147-203. La pobreza de la documentación municipal astorgana de 
ciudades donde el obispo goza de poderes jurisdiccionales, aún parciales como en el caso de las tres sedes episcopales asturleonesas, las autoridades concejiles van a entrar en constante conflicto con el poder eclesiástico ${ }^{38}$, y la exención fiscal de la que gozan los excusados de la Iglesia será puesta en cuestión sistemáticamente ${ }^{39}$.

No es de extrañar entonces que en Astorga, León y Oviedo las referencias a enfrentamientos concejo-Iglesia en torno a los excusados se concentren en el siglo XIII y en particular durante el reinado de Alfonso X, que los estudiosos coinciden en señalar como una época decisiva en la afirmación de los sistemas hacendísticos municipales ${ }^{40}$.

Precisamente de época de ese monarca datan los únicos testimonios que tenemos sobre esta cuestión para Astorga en el siglo XIII: en 1257 el obispo y el concejo llegaron a un acuerdo acerca de la cuantía y procedencia de los excusados episcopales, pero del diploma que lo recogía sólo ha llegado hasta nosotros una breve noticia, por lo que resulta imposible conocer los detalles del mismo ${ }^{41}$; y en 1274 el soberano ordena al concejo que no haga pagar a dichos excusados ${ }^{42}$. Las siguientes noticias acerca de posibles disputas en torno a esta cuestión son ya de época Trastámara, y se refieren a otro tipo de excusados: en 1374, ante la queja del cabildo de que el concejo no respetaba la antigua exención de los excusados de la obra de la catedral, Enrique II manda cumplir el privilegio ${ }^{43}$ (cuya fecha original nos es, recordemos, desconocida ${ }^{44}$ ); en 1378 el juez real en Astorga sentencia que los canónigos, sus familiares y criados están exentos del tributo de la moneda ${ }^{45} ; \mathrm{y}$, finalmente, en 1380 Juan I ordena al concejo respetar el "inmemorial" ${ }^{46}$ privilegio de los excusados "de abastecimiento"

Para Oviedo las noticias acerca de conflictos en torno a los excusados son especialmente escasas, aunque arrancan también en época de Alfonso X. En 1268

época plenomedieval impide conocer los orígenes y consolidación de la hacienda concejil, que para los siglos XV-XVI ha sido estudiada en J.A. Martín Fuertes, El concejo de Astorga (siglos XIII-XVI), León, 1987, pp. 261-328.

38. Ruiz de la Peña Solar, "Las ciudades de señorío eclesiástico...”, op.cit., pp. 113-145. El caso ovetense ha sido analizado con especial detalle en J.I. Ruiz de la Peña Solar, S. Beltrán Suárez, "Señoríos compartidos, señoríos conflictivos. Los obispos y el concejo de Oviedo en la Edad Media", en G. Cavero Domínguez (coord.), Iglesia y ciudad. Espacio y poder (siglos VIII-XIII), León, 2011, pp. 137-177, y para el caso leonés puede acudirse a Nieto Soria, "Los obispos de la diócesis de León...", op.cit., pp. 240-6.

39. Nieto Soria, Iglesia y poder real en Castilla..., pp. 170-1; Ruiz de la Peña Solar, "Las ciudades de señorío eclesiástico...”, op.cit., pp. 131-3.

40. Vid. referencias en nota 37.

41. Cavero Domínguez, Martín López, Colección documental... II, op. cit., doc. nº 1287, p. 467.

42. Cavero Domínguez, Martín López, Colección documental... II, op. cit., doc. $\mathrm{n}^{\circ}$ 1378, p. 507.

43. Cavero Domínguez, Domínguez Sánchez, Colección documental... III, op. cit., doc. nº 1807, p. 275 .

44. Vid. nota 26.

45. Cavero Domínguez, Domínguez Sánchez, Colección documental... III, op. cit., doc. $\mathrm{n}^{\circ} 1820$, p. 281.

46. Vid. nota 33.

47. Cavero Domínguez, Domínguez Sánchez, Colección documental... III, op. cit., doc. $\mathrm{n}^{\circ} 1828$, p. 287 . 
se desarrolló un pleito muy interesante entre el concejo y dos individuos, Pedro Vega y Ruy Pérez ${ }^{48}$. Éstos pretendían gozar de la condición de excusados, dado que ambos eran oficiales del obispo (el uno repostero y el otro escribano), pero el concejo consideraba que debían pagar como vecinos, dado que "seyan casados con sus vezinas e carreavan heredades rengalengas e foreras so su poderio", así como "compravan e vendian con ellos e venían a su juyzio". A pesar de que aquéllos alegaban que eran hombres del obispo, "e que el obispo e el cabildo avían previlegios de los reys por que los sus omnes eran escusados de todo pecho e de toda fazendera", y de que el procurador del cabildo llegó a presentar un privilegio de Alfonso IX en este sentido, el rey sentenció en favor del concejo. No obstante, el monarca no entra en el fondo del asunto y no pone en cuestión la validez del privilegio, sino que parece basar su decisión en el hecho de que, tal y como relata el procurador del municipio, Pedro Vega y Ruy Pérez habían hecho avenencia con el concejo "de pechar con ellos e pecharon, e assí se quitaran del privilegio si lo por si avían". Después de esta sentencia de Alfonso X sólo tenemos otra noticia relativa a los conflictos entre las autoridades concejiles y los excusados de la Iglesia en Oviedo, una noticia escueta pero ciertamente significativa: sabemos que Alfonso XI, en fecha desconocida, sentenció en un pleito entre el concejo ovetense y los excusados del obispo que estos debían pagar y contribuir, a pesar del privilegio ${ }^{49}$.

De cualquier modo, el caso mejor documentado para el ámbito de estudio del presente trabajo es sin duda el de León, donde las autoridades concejiles librarán largos pleitos contra la Iglesia sobre múltiples asuntos, entre los que figura recurrentemente la cuestión de los excusados. Ya en 1241 el concejo se quejaba al rey de que el obispo y los canónigos tomaban excusados "quales non devíen" 50 , y la cuestión parece seguir abierta en los años 60, cuando se desarrolla un largo pleito que da lugar en 1269 a una avenencia que recoge las quejas de cada una de las partes $^{51}$. Entre otras muchas cosas, los representantes eclesiásticos se quejaban de que el concejo prendaba contra derecho a ciertos hombres pobres a los que la Iglesia daba casas para residir sin pagar alquiler alguno, así como a los hospitaleros, mayordomos y merinos de la Iglesia. Por su parte, las reclamaciones de los representantes concejiles mencionan que el obispo tomaba indebidamente excusados de cuantía mayor de 300 maravedís y que los pedreros de la Iglesia no contribuían en las cargas del concejo, a pesar de carecer de privilegio de exención. En ambos casos las quejas son atendidas por la parte contraria, que se aviene a abandonar las prácticas motivo de reclamación. Pero lo que ofrece especial interés de este acuer-

48. Miguel Vigil, Colección... op. cit., doc. nº XXXIII, p. 60.

49. Se trata del regesto de un original perdido, recogido en el inventario de documentos del archivo municipal ovetense de 1536 y editado en Miguel Vigil, Colección... op. cit., p. 324, doc. $\mathrm{n}^{\circ}$ 231: "Sentencia y Carta ejecutoria del Rey D. Alfonso XI, en el pleito litigado entre los Escusados del Obispo con el concejo de Oviedo, los cuales no querían pagar ni contribuir; y se manda lo ejecuten, no obstante el privilegio".

50. Ruiz Asencio, Colección documental... VIII, op. cit., doc. nº 2041.

51. Ruiz Asencio, Martín Fuertes, Colección documental... IX, op. cit., doc. no 2296. 
do no es tanto la resolución (al menos temporal ${ }^{52}$ ) del conflicto como las razones que subyacen a las protestas, particularmente en dos puntos. Por un lado, las partes aluden constantemente a la "costume agardada de L annos acá", lo que parece señalar al reinado de Alfonso IX como época en la que pudo fijarse un primer modus vivendi entre la incipiente institución concejil y las autoridades eclesiásticas, con acuerdos precisos como el de que los excusados del obispo no sobrepasasen la cuantía de 300 maravedís ${ }^{53}$. Por otro lado, en las argumentaciones del concejo late la sospecha permanente de que la Iglesia pueda conducirse de manera dolosa en el asunto de los excusados, por lo que insisten en que respetarán las exenciones como se les pide "quando esto se fiçiesse sien enganno del rrey e del conceyo", esto es, cuando los supuestos pobres sean efectivamente "muy povres e non oviessen nenguna heredat por que deviessen a pechar", y cuando "estos maordomos e merinos fuessen paniguados de los de la yglesia e usassen del so officio" y "quando elos espitaleros non fuessen arrendadores e usassen de so officio". Es decir, las autoridades municipales son conscientes de que la Iglesia está utilizando las figuras de exención de que dispone en un sentido que no se corresponde con su función teórica, y que más que como medida de protección de sus domésticos y oficiales se están empleando torticeramente para dotar de exención fiscal a pecheros de buena posición económica. La fijación de una cuantía máxima de 300 maravedís para la riqueza de los excusados, seguramente ya en época de Alfonso IX, es una buena muestra de ese temor, y no hay que olvidar que ese mismo monarca, al reconocer que al obispo de Astorga le correspondían 22 excusados, establecía "que de melioribus omnes non excuset" ${ }^{54}$.

Otro punto que habría de enfrentar largamente al concejo e iglesia leoneses es la pretensión del primero de que los excusados de la Iglesia contribuyesen en el pago de la soldada del juez de salario de León ${ }^{55}$. Según se nos relata en una querella presentada en torno al año 1270, 6 o 7 años después de que Alfonso X hubiese establecido la figura del juez de salario en León el concejo comenzó a prendar a los excusados, lo que le valió la excomunión, que sólo se levantó una vez que fue devuelto lo prendado. No obstante, más adelante las autoridades concejiles aprovecharon la ausencia del obispo, que había ido "a la corte de Roma en servicio del rey", para volver a tomar prendas, quebrantando las casas de los canónigos, vasallos y excusados de la Iglesia ${ }^{56}$. El conflicto debió de prolongarse durante décadas, porque todavía en 1305 se establece una avenencia entre ambas partes, por

52. En 1284 la iglesia de León se queja a Sancho IV de que el concejo está quebrantando el acuerdo de 1269, a pesar del compromiso de respetarlo en tanto los pleitos, que aún siguen pendientes, no hayan concluido en sentencia: Ruiz Asencio, Martín Fuertes, Colección documental... IX, op. cit., doc. $\mathrm{n}^{\mathrm{o}} 2443$.

53. Por un acuerdo de 1241 entre el concejo de León y la colegiata de San Isidoro sabemos que precisamente esa misma condición se había puesto a los excusados isidorianos "en tiempo del rey don Alffonsso" (Rodríguez Fernández, "El señorío isidoriano....", op. cit., doc. nº 6, p. 246).

54. Vid. nota 12.

55. Nieto Soria, "Los obispos de la diócesis de León...”, op. cit., pp. 236-7.

56. Ruiz Asencio, Martín Fuertes, Colección documental... IX, op. cit., doc. no 2296. 
la cual el concejo renuncia a exigir pagos a los excusados del obispo y de la obra sobre este concepto ${ }^{57}$.

Un frente adicional parece abrirse en 1284, cuando el obispo se queja al rey de que el concejo exige ahora que sus 12 excusados, que estaban encargados de guardar una puerta de la ciudad sita entre la catedral y el palacio episcopal, acudan a los apellidos concejiles, aún cuando se hacen "sen seer la senna de la villa sacada o el conceyo comunalmientre apregonado pora ello", y si no lo hacen, les toman prendas "en guisa que pechan más en aquestas penas ca pecharían en otra manera se fuessen pecheros", añadiendo que "en esta manera non pued aquella

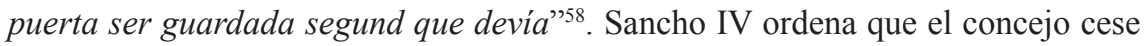
en su exigencia, por cuanto los excusados del obispo "acostumbraron ser quitos de hueste e de todo otro pecho" 59 .

Y aún este mismo monarca tuvo que intervenir de nuevo en 1289 para ordenar al concejo que no hiciese pagar a los excusados del obispo, el cabildo o la obra de la catedral y respetase sus privilegios de exención ${ }^{60}$.

Aunque en adelante carecemos de noticias tan detalladas como las que hemos visto para el siglo XIII, parece que a lo largo de la centuria siguiente el concejo de León no renunció a sus pretensiones de hacer contribuir a los excusados de la Iglesia, pues tenemos testimonios al respecto de época de Pedro $\mathrm{I}^{61}$, y los primeros monarcas de la casa Trastámara dan órdenes expresas a las autoridades concejiles para que respeten sus privilegios de exención, que habían quebrantado, y se guarden ciertos usos y composiciones de época de Alfonso XI ${ }^{62}$. La cuestión estaba no obstante lejos de resolverse, porque todavía a lo largo del siglo XV los excusados de la Iglesia serían objeto de disputa, dentro ya de otras coordenadas políticas y sociales $^{63}$.

Como conclusión de este apartado podría decirse que el desarrollo de los conflictos concejo-Iglesia en torno a los excusados se caracteriza por una tensión per-

57. Martín Fuertes, Colección documental... XI, op. cit., doc. $\mathrm{n}^{\circ} 2760$.

58. Ruiz Asencio, Martín Fuertes, Colección documental... IX, op. cit., doc. $\mathrm{n}^{\circ} 2440$.

59. Dada esta situación, no es de extrañar que cuando en 1291 el cabildo de León solicita de Sancho IV confirmación de un viejo privilegio de 1047 en el que Fernando I prohibía a los sayones reales entrar en las posesiones de la iglesia leonesa (Ruiz Asencio, Martín Fuertes, Colección documental... $I X$, op. cit., doc. $\left.\mathrm{n}^{\circ} 2554\right)$, le presenten una versión adulterada, de la que significativamente ha desaparecido una cláusula a todas luces molesta que decía así: "excepto ut faciant illos homines nostro fossato et in illa civitate de Legione ut habeant nostros maiorinos suo foro, sicut fuit usuale ab antecessoribus nostris et prioribus regibus qui ante nos precesserunt" (Ruiz Asencio, Colección documental... IV, op. cit., doc. $\left.\mathrm{n}^{\circ} 1048\right)$.

60. Ruiz Asencio, Martín Fuertes, Colección documental... IX, op. cit., doc. $\mathrm{n}^{\circ} 2528$.

61. Martín Fuertes, Colección documental del Archivo Municipal ..., op. cit., docs. $\mathrm{n}^{\mathrm{o}}$ 153, pp. 215-7 (año 1350), no 172 , pp. 241-3 (año 1352) y nº186, pp. 257-9 (año 1359).

62. Documento $n^{\circ} 4$ del Apéndice Documental (año 1370) y C. Álvarez Álvarez, Colección documental del Archivo de la Catedral de León, XII (1351-1474), León, 1995, docs. nº 3218 (año 1372), $n^{\circ} 3244$ (año 1376), no 3276 (año 1380) y no 3304 (año 1389).

63. Santamarta Luengos, Señorío y relaciones de poder.. op. cit., pp. 172-198; R. González González, "Construir la identidad pechera: la lucha contra la exención fiscal en Astorga, León y Oviedo durante el siglo XV”, en J.A. Solórzano Telechea, B. Arízaga Bolumburu y J. Haemers (eds.), Los grupos populares en la ciudad medieval europea, Logroño, 2014, pp. 523-541. 
manente que requiere de acuerdos periódicos. La primacía de estas composiciones es tal que pueden llegar a anular el propio privilegio, tal y como veíamos para Oviedo en 1268, o servir de referente durante décadas, como la avenencia leonesa de 1269. Es decir, aún los privilegios de exención otorgados o reconocidos por la monarquía requieren de una negociación a nivel local que fije ciertos límites y condiciones a través de acuerdos entre las partes, en un proceso que puede necesitar reajustes a lo largo del tiempo, en función de la evolución del juego de fuerzas dentro del sistema de poder urbano.

\subsection{La posición de la monarquía}

A lo largo de los siglos XIII-XIV los reyes parecen situarse casi invariablemente del lado de la Iglesia en estos conflictos, ordenando periódicamente a los concejos que respeten la exención fiscal de los excusados ${ }^{64}$. Con una excepción importante: los reinados de Alfonso XI y de Pedro I.

En efecto, Alfonso XI parece haber mostrado una especial dureza frente a las exenciones fiscales, apoyando firmemente las reclamaciones de las autoridades concejiles, como queda patente en diversos mandatos conservados en el archivo del consistorio leonés: en 1335 el rey ordena al juez real en León que obligue a contribuir en el pago de su salario a los que se dicen exentos por ser monederos o excusados y vasallos de monasterios y caballeros, "non mostrando privilegios nin cartas porque devan seer escusados de soldada de juez"65; y en 1339 manda que sean obligados a contribuir en los repartimientos y derramas concejiles tanto los excusados de la colegiata de San Isidoro ${ }^{66}$ como los menestrales que tengan cartas o sentencias de hidalguía ${ }^{67}$. Además, como ya hemos visto, sabemos que este monarca también sentenció en fecha indeterminada que los excusados del obispo de Oviedo debían contribuir en los pagos concejiles ${ }^{68}$. Es más, por un testimonio de 1355 parece que Alfonso XI incluso debió de negarse a confirmar el viejo privile-

64. Existen mandatos al respecto de Alfonso X (Cavero Domínguez, Martín López, Colección documental... II, op. cit., doc. $\mathrm{n}^{\circ}$ 1378, p. 507), Sancho IV (Ruiz Asencio, Martín Fuertes, Colección documental... IX, op. cit., docs. $\mathrm{n}^{\circ} 2440 \mathrm{y} \mathrm{n}^{\circ}$ 2528), Enrique II (documento $\mathrm{n}^{\circ} 4$ del Apéndice Documental; Álvarez Álvarez, Colección documental... XII, op. cit., docs. no 3218 y no 3244; Cavero Domínguez, Domínguez Sánchez, Colección documental... III, op. cit., doc. nº 1807, p. 275) y Juan I (Álvarez Álvarez, Colección documental... XII, op. cit., docs. no 3276 y no 3304; Cavero Domínguez, Domínguez Sánchez, Colección documental... III, op. cit., doc. nº 1828, p. 287). Además, para Fernando IV y la minoría de Alfonso XI conservamos sendas órdenes para que se respete a los excusados de la iglesia de León, dirigidas no a los concejos sino a los recaudadores reales: Martín Fuertes, Colección documental... XI, op. cit., docs. $\mathrm{n}^{\mathrm{o}} 2755$ (año 1304) y n ${ }^{\circ} 2891$ (año 1317).

65. Martín Fuertes, Colección documental del Archivo Municipal ..., op. cit., doc. no 99, pp. 143-4.

66. Martín Fuertes, Colección documental del Archivo Municipal ..., op. cit., doc. $\mathrm{n}^{\circ} 125$, pp. $173-4$

67. Martín Fuertes, Colección documental del Archivo Municipal ..., op. cit., doc. $\mathrm{n}^{\circ} 126$, pp. $174-5$.

68. Vid. nota 49. 
gio de los excusados de la iglesia ovetense ${ }^{69}$, contenido al parecer en un documento de Alfonso X del que no hemos conservado más noticias ${ }^{70}$.

Pedro I parece haber continuado en buena medida la política pro-concejil de su padre. Así, si en 1350 comisiona a García Alfonso Triguero para hacer justicia en los "grandes bolliçios e escándalos" que oponían a la iglesia de León y sus hombres, vasallos y excusados con el municipio ${ }^{71}$, en 1352, ante las quejas del concejo de León de "que non quieren pagar con ellos los más de los moradores de la dicha çibdat e otros que moran en la alfoz e término de la dicha çibdat" ${ }^{\prime 2}$, Pedro I reafirma su ordenamiento dado en las cortes de Valladolid de 1351 para que todos ellos contribuyan en los pechos y derramas concejiles y emplaza a los que tengan derechos de exención a acudir ante él para que lo mande "oyr e librar commo la mi merçed fuere e fallare por derecho" 73 . Finalmente, en 1359, con motivo del conflicto en torno a una derrama concejil "para ajuda de los omes de cavallo que están en nonbre del dicho conçeio por fronteros en Aragón en mío serviçio" en la que las autoridades municipales pretendían hacer contribuir a los carniceros de la Iglesia, el rey ordena en términos perentorios al obispo de León no sólo que haga pagar a sus carniceros, sino que levante la excomunión que había lanzado contra los oficiales concejiles encargados de la recaudación, añadiendo que "daquí adelantre nos vos atrevades a poner tales sentençias de escomunión contra las mis justiçias e offiçiales de la mi çibdat" ${ }^{\prime 74}$.

Para Oviedo la postura de Pedro I parece haber sido mucho más tibia, pues, a diferencia de su padre, acaba confirmando en 1355 a la iglesia ovetense el privilegio de nombrar una amplia nómina de excusados ${ }^{75}$. De todos modos, es significativo que la confirmación no fuese automática, sino que, a pesar de que los procuradores de la Iglesia le habían presentado un mandato de Alfonso X al respecto, el monarca ordenase hacer una pesquisa en la que el obispo y cabildo debían "provar si usaran de la dicha carta e si les fuera gardada", amparándose precisamente en la falta de confirmación del mismo por parte de Alfonso XI.

En cualquier caso, dejando a un lado el ejemplo ovetense, parece evidente que al menos los concejos de León y Astorga aprovecharon la nueva política de la

69. Tal y como afirma Pedro I, "non apparesçía confirmaçión del rey don Alfonso, mio padre, que Dios perdone" (documento $\mathrm{n}^{\circ} 3$ del Apéndice Documental).

70. Vid. apartado 2.1.

71. Martín Fuertes, Colección documental del Archivo Municipal ..., op. cit., doc. $\mathrm{n}^{\mathrm{o}}$ 153, pp. 215-7. No tenemos noticias sobre el resultado de esta comisión.

72. Para lo cual alegaban diversas condiciones de exención, entre las que figuran los excusados del obispo y la Iglesia: "diziendo que los unos son apaniguados de clérigos e los otros monederos e los otros escusados del obispo e de su eglesia e de los abades e de las órdenes e otros que se llaman fijosdalgo e otros asentados e de encomiendas, assí que tan pocos son los que fincan para pechar que non pueden conplir nin fazer aquellas cosas que son mío serviçio e pro comunal de la dicha çibdat" (Martín Fuertes, Colección documental del Archivo Municipal ..., op. cit., doc. no 172, p. 241-2).

73. Martín Fuertes, Colección documental del Archivo Municipal ..., op. cit., doc. n 172 , p. 241-3.

74. Martín Fuertes, Colección documental del Archivo Municipal ..., op. cit., doc. $\mathrm{n}^{\circ} 186$, pp. 257-9.

75. Documento $n^{\circ} 3$ del Apéndice Documental. 
monarquía durante los reinados de Alfonso XI y Pedro I para ignorar la exención de los excusados de la Iglesia y obligarlos a contribuir. Sin embargo, esta nueva coyuntura se mostraría efímera: con la llegada de los Trastámara al poder la monarquía cierra filas en torno a la Iglesia y se sitúa inflexiblemente de su lado en las disputas sobre los excusados, existiendo instrucciones precisas de Enrique II y Juan I a las autoridades municipales de ambas ciudades para que respeten sus privilegios, que habían sido quebrantados por los concejos ${ }^{76}$. De forma significativa, en este momento los privilegios de excusados reciben ya el calificativo de "antiguos" e "inmemoriales", incluso cuando datan de época de Fernando IV"7.

\subsection{Conflictos con los agentes del fisco regio}

Precisamente de época de Alfonso XI datan los únicos conflictos que tenemos documentados para el ámbito de estudio del presente trabajo entre los excusados de la Iglesia y los recaudadores reales. Se trata de sendos enfrentamientos de los cogedores de la fonsadera de 1330 y 1340 en León con los representantes del obispo y cabildo leoneses, sobre los que ha trabajado ya el profesor Santamarta Luengos $^{78}$.

En septiembre de 1331, a demanda de los cogedores de la fonsadera del año anterior, Alfonso XI ordena a los concejos de León y el valle de Torío que obliguen a pagar dicho tributo a todos los que se niegan a ello alegando ser excusados de las iglesias y abadengos, hidalgos o monederos, "non aviendo tales previllejos nin cartas (...) por que devan ser quitos de non pagar fonsadera" $"$. Amparados por el mandato regio, los cogedores Juan Alfonso y Fernán Álvarez de Oviedo prendaron por dicho tributo a los vasallos y excusados de la iglesia y la obra de León, motivando un pleito ante los jueces del rey en la ciudad de León. Los representantes de la Iglesia alegan que cuentan con privilegios por los que sus vasallos y excusados

76. Vid. nota 62. Es también llamativo que date precisamente de época de Enrique II la sentencia de un juez real en Astorga que declara que los canónigos y sus familiares y criados están exentos del pago de la moneda: vid. nota 45. Además, para el caso leonés, varias de las disposiciones regias citadas ordenan respetar ciertos acuerdos, usos y costumbres que supuestamente datarían de época de Alfonso XI. Dada la política decididamente pro-concejil de este monarca en el asunto de los excusados, el hecho resulta chocante. Quizás se trate de un mero recurso propagandístico que pretende presentar la política de los Trastámara como una restauración de la "recta vía" anterior a las turbulencias del reinado de Pedro el Cruel; o más probablemente una alusión a algún tipo de acuerdo establecido durante la minoría de Alfonso XI, cuando sabemos por ejemplo que el obispo de Oviedo aprovechó el inestable clima político y la indefensión de las autoridades municipales para imponer un nuevo orden en la ciudad especialmente beneficioso para los intereses de la Iglesia, a través de una avenencia con el concejo fechada en 1314, la cual sería anulada al año siguiente por Alfonso XI, a través de sus tutores, por cuanto otorgaba al obispo y cabildo "más poderío en la villa de Oviedo (...) de quanto nunca usastes", según la disposición revocatoria confirmada por el monarca en 1336, siendo ya mayor de edad: vid. Ruiz de la Peña Solar, S. Beltrán Suárez, "Señoríos compartidos...", op. cit., pp. 175-7, y Miguel Vigil,

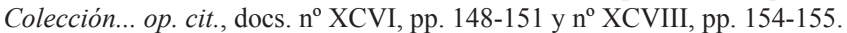

77. Vid. notas 15,26 y 33.

78. Santamarta Luengos, Señorío y relaciones de poder... op. cit., pp. 175, 182 y 185; J.M. Santamarta Luengos, "Fiscalidad regia en León, 1250-1350", Hispania, 208 (2001), pp. 503-505.

79. Documento $\mathrm{n}^{\circ} 2$ del Apéndice Documental. 
están exentos de todo tributo regio, incluida la fonsadera, y que además el cogedor Juan Alfonso había reconocido ante el obispo, según constaba en un instrumento notarial,

\begin{abstract}
"que sobiera en buena verdad por omnes bonos, ricos e ançianos e de bona fama e que fallara que los vasallos e los escusados e sergentes quel obispo e el cabildo de la dicha eglesia avían aqui en León e en la sacada de aqui de León, que nunca dieran fonsadera al dicho sennor rey nin a ninguno de los otros reys que fueran ante dél, onde él viene, en ningún tienpo; e que lles fueran sienpre guardados los privilegios e cartas que avían de los reys (...) E que él, obedesçiendo los dichos privilegios e cartas (...) sobre fecho de la dicha fonsadera e por la verdat que sobiera sobrello (...) que se partía de lles demandar e los dava por livres e quitos della para agora e para adelantre"
\end{abstract}

Sin embargo, los recaudadores reales parecen entender que el expreso mandato regio de septiembre invalida todas esas objeciones, e insisten a los jueces para que lo hagan cumplir, quejándose de que les han presentado el mandato el día 29 de noviembre, ante notario, "e después acá muchas vezes", obteniendo por única respuesta maniobras dilatorias. Finalmente, el 17 de diciembre los jueces pronuncian sentencia, en la que declaran que de acuerdo con los privilegios los excusados de la obra están exentos del pago de fonsadera, mientras que en lo que respecta a los excusados del obispo y vasallos de éste y el cabildo no dan una respuesta definitiva, por cuanto "querían aver conseio (...) e farían sobrello lo que fallasen por derecho" $"$. Aunque no sabemos si se llegó a alguna decisión con respecto a los excusados del obispo, los vasallos del obispo y cabildo sí lograron verse finalmente exentos, pues en 1332 Alfonso XI ordena que no paguen la fonsadera, ya que están exentos por corresponderles el pago de acémilas ${ }^{81}$.

Un nuevo episodio de este conflicto tiene lugar en 1340, cuando Sancho Díez de Sahagún, cogedor de la fonsadera en la sacada de León, prende a los excusados de la obra de la catedral. Parece hacerlo de conformidad con el mandato regio de enero de dicho año, dirigido al concejo de León, en el que Alfonso XI ordenaba que todos contribuyesen en la fonsadera, salvo las excepciones que cita expresamente, entre las que no figura alusión alguna a excusados de la Iglesia ${ }^{82}$. De nuevo el asunto acaba en un pleito ante los jueces del rey en la ciudad de León ${ }^{83}$. Sin embargo, Sancho Díez va más allá que los recaudadores anteriores, y cuando los representantes de la Iglesia presentan los privilegios que eximen de tributos a los excusados de la obra, exige que se le presente una lista de "quáles eran los

80. Martín Fuertes, Colección documental... XI, op. cit., doc. nº 2992.

81. Martín Fuertes, Colección documental... XI, op. cit., doc. n 2996. Ambos tributos eran incompatibles, según expone Ladero Quesada, Fiscalidad y poder real... op. cit., p. 46.

82. Los únicos exentos del pago serían los caballeros armados de rey o infante heredero, los oficiales de la casa del rey, los ballesteros del rey, las personas impedidas para acudir al fonsado (mujeres, niños, ancianos e inválidos) y las villas y lugares que cuentan con privilegios al respecto: Martín Fuertes, Colección documental... XI, op. cit., doc. $\mathrm{n}^{\circ} 3058$.

83. Martín Fuertes, Colección documental... XI, op. cit., doc. n ${ }^{\circ} 3061$. 
escusados que avían de la dicha obra" (recordemos que los privilegios establecían el número de 22 excusados, fijados en principio para unas profesiones concretas y ampliados luego a cualquier menestral ${ }^{84}$ ). Los procuradores del cabildo presentan una nómina de 21 personas que ejercen los más diversos oficios, justificándose en los casos que podrían parecer chocantes cuál es su relación con la construcción de la catedral: el maestro de la obra, 1 vidriero, 7 pedreros, 1 herrero, 1 hortelano ("porque lo que llavra es para la obra"), 1 mercader ("que trae las colores"), 1 barbero ("del obispo e de los de la obra"), 1 peletero ("que da las lluvas para los de la obra"), 2 sastres (de los que se dice que cosen los paños para los que trabajan en la obra), 1 carnicero ("que da los cueyros para las colleras"), 1 correero ("cose e faz las pareyas"), 1 fabricante de calzas, 1 carpintero ("faz los plancheles e cubre la eglesia") y 1 carretero ("trae los cantos"). Sin embargo, a pesar de los imaginativos intentos del cabildo por hacer pasar por excusados de la obra a individuos de profesiones tan dispares, el cogedor Sancho Díez sólo acata como excusados por así decir "legítimos" al maestro de la obra, el vidriero, los siete pedreros, el mercader (designado por él como "el que traya las colores para las pinturas") y el herrero ("que llavrava la ferramienta para la dicha obra"), no reconociendo al resto de personas incluidas en la nómina, ya que "no eran pertenesçientes para la dicha obra". El procurador del cabildo solicita no obstante a los jueces que sentencien que todos los incluidos en la lista están exentos como excusados de la obra

"por quanto los otros sobredichos pedreros non podían llavrar enna dicha obra sien el mester destos, mayormientre que enna dicha carta del rey se contenía que los pedreros que los podiese el obispo e el cabillo remover en otras personas de quales menester quier que les conplise" 85 .

Finalmente, los jueces emiten su sentencia el 19 de junio, declarando exentos del pago de la fonsadera a los 11 menestrales reconocidos como excusados por el recaudador, mientras que acerca de los otros afirman que "queremos aver nuestro conseyo qué es aquello que devemos a fazer con derecho".

En resumen, puede decirse que durante el reinado de Alfonso XI los recaudadores de la fonsadera en León someten a un verdadero cerco a los excusados de la Iglesia, luchando contra unas arraigadas tradiciones de exención que no tienen pleno respaldo documental. Así, en 1331 parecen conseguir que el marco de la exención fiscal legítima quede reducido a los excusados de la obra, mientras que en 1340 incluso éstos son cuestionados, tratando de ponerse freno a lo que podría ser la inveterada costumbre del cabildo de aprovechar el privilegio de Sancho IV de 1290 para excusar como pretendidos trabajadores de la obra a individuos sin conexión real con las tareas constructivas. Sin embargo, y a pesar de contar en su favor con la firmeza de la postura regia en cuanto a las pretensiones injustificadas de exención, los recaudadores reales chocan con la inercia de los juegos de poder locales, de modo que los jueces tratan por todos los medios de evitar pronunciar

84. Vid. notas 24 y 25.

85. Se refiere al privilegio de Sancho IV de 1290: vid. nota 25. 
una sentencia lesiva para los intereses de la Iglesia, fundamentalmente a través de maniobras dilatorias. Ello resulta especialmente patente en las propias sentencias emitidas, que son particularmente claras en lo que atañe a los individuos considerados efectivamente exentos, mientras que rehúyen dar un juicio definitivo acerca de los demás, solicitando examinar de nuevo las pruebas presentadas y reflexionar aún más al respecto.

\section{EXCUSAdOS Y SOCIEDAD URBANA: UN ACERCAMIENTO PROSOPOGRÁFICO}

Para concluir este trabajo, trataré de ofrecer una perspectiva de pequeña escala acerca de la integración de los excusados de la Iglesia en la sociedad urbana. Para ello aprovecharé un documento de extraordinario interés: la nómina de excusados "de servicio" del obispo y cabildo de Oviedo que fue elaborada en 1301 con finalidad desconocida ${ }^{86}$. Gracias a que en este caso puede saberse exactamente qué personas se beneficiaban del privilegio de excusados, trataré de analizar cuál era su posición en la sociedad local a fin de calibrar el valor de esta figura en las relaciones sociales y de poder dentro de la comunidad urbana. Para ello he llevado a cabo una encuesta prosopográfica en torno a los 187 individuos que figuran como excusados en la lista, logrando obtener algún dato relevante de 115 de ellos, es decir, el $61 \%$ del total ${ }^{87}$.

Para empezar, he logrado identificar la profesión de 92 excusados (la nómina sólo señala la ocupación de 66), es decir, casi la mitad del total y el $80 \%$ de los incluidos en la tabla prosopográfica. De estos 92, más de la mitad (concretamente el 58\%) ejercen oficios manuales, entre los que ocupan un lugar destacadísimo las profesiones relacionadas con la industria textil y el trabajo de la piel: un total de 31, repartidos en 12 sastres, 7 peleteros, 7 vaineros, 4 zapateros y 1 cordonera. Muy por detrás se sitúan los sectores de la artesanía del metal (3 "luqueteros" o fabricantes de pestillos, 2 cerrajeros, 2 cuchilleros, 2 herreros y 2 orfebres) o la alimentación (6 hortelanos y 4 carniceros), mientras que el ámbito de la construcción y el trabajo de la madera aparece únicamente representado por un carpintero. La fuerte presencia de estos menestrales entre los excusados "de servicio" resulta seguramente esperable, pues el clero capitular pertenece al estrato superior de la sociedad urbana, con un estilo de vida que

86. Documento $\mathrm{n}^{\mathrm{0}} 1$ del Apéndice Documental.

87. El resultado de esta encuesta prosopográfica se muestra en la Tabla 1, ofrecida en apéndice. La realización de la misma hubiera sido seguramente imposible sin la generosidad de Olaya Rodríguez Fueyo, doctoranda del Área de Ciencias y Técnicas Historiográficas del Departamento de Historia de la Universidad de Oviedo, donde desarrolla actualmente su tesis doctoral acerca de la primera fase del notariado en la ciudad de Oviedo, desde las últimas décadas del siglo XIII hasta mediados del siglo $\mathrm{XIV}$, investigación que habrá de marcar un hito en el medievalismo asturiano al ofrecer la primera interpretación de conjunto de la época de mayor producción documental conservada para todo el período medieval en la región. Quede aquí constancia del mayor de mis agradecimientos por haberme facilitado sus transcripciones de unos 500 documentos inéditos y mi reconocimiento hacia una excelente investigadora. 
hace de la ostentación y el lujo uno de sus principales signos de distinción ${ }^{88}$, por lo que probablemente aprovechaban el privilegio de excusados para integrar en su clientela a personas dedicadas a oficios manuales que pudieran garantizar su abastecimiento al margen del mercado.

Sin embargo, llama la atención un segundo grupo nada desdeñable, ya que supone el $40 \%$ del total de excusados cuya profesión conocemos, integrado por 37 individuos que ejercían los oficios de mercader, tendero o cambista ${ }^{89}$. Esta importante representación del sector del comercio y las finanzas entre los excusados "de servicio" puede tener una primera lectura relacionada con la explicación que acabo de formular para los menestrales, pues sobre todo en el caso de mercaderes y tenderos podría estar hablándonos de las necesidades de aprovisionamiento de los capitulares, en particular en lo que se refiere a productos de lujo. Pero, sin negar esa realidad, el hecho de que en una obra ya clásica el profesor Ruiz de la Peña señalase precisamente al ejercicio de las profesiones de mercader, tendero y cambista como "la actividad económica característica de los representantes del 'patriciado urbano' ovetense en la plena Edad Media"90 debería hacernos sospechar que la figura de los excusados se está utilizando para dotar de exención fiscal a individuos que pertenecen al grupo dirigente.

Esa impresión se refuerza si pasamos a considerar el perfil político de los excusados. No sólo llama la atención que varios de ellos llegasen a ocupar las principales magistraturas urbanas, como las de juez o alcalde, sino que cuando conocemos la profesión de estos excusados que ejercieron cargos públicos vemos que, con una única excepción (la del herrero Johan Bartolomé, que fue alcalde en 1312), se trata siempre de los mismos oficios: mercader, tendero o cambista. Así pues, puede afirmarse que dentro de los pretendidos excusados "de servicio" del clero capitular existe un núcleo de individuos que forman parte del grupo de familias que ejercen un papel rector en la ciudad a través de la acumulación de fortuna y poder.

Así, aparece por ejemplo muy bien representado en la lista de exentos el círculo de uno de los principales prohombres ovetenses de la época, el cambista y alcalde del rey Alfonso Nicolás ${ }^{91}$ : encontramos en ella a su yerno Aparicio Fernándiz, a sus hombres de confianza Pedro Franco y Fernán Nicolas, a Taresa Alfonso de la Rúa, viuda de su hermano, y a Luques Rodríguiz, yerno de ésta. Además, si para algunos excusados tenemos documentado además un índice de superioridad social tan claro como el hecho de contar con criados y clientes, tal

88. Según expone con toda claridad Suárez Beltrán, El cabildo de la catedral... op. cit., pp. 261-274.

89. Contamos concretamente con 19 individuos identificados exclusivamente como mercaderes, 4 exclusivamente como cambistas, 4 exclusivamente como tenderos, 4 como mercaderes y cambistas, 3 como tenderos y cambistas, 1 como mercader y tendero, 1 como tendero y ofrebre y 1 como mercader y peletero.

90. J.I. Ruiz de la Peña Solar, El comercio ovetense en la Edad Media, Oviedo, 1990, p. 180.

91. A quien el profesor Ruiz de la Peña dedicó un estudio modélico: J.I. Ruiz de la Peña Solar, "Alfonso Nicolás, burgués de Oviedo y alcalde del rey", Asturiensia Medievalia, 2 (1975), pp. 113-176. 
como ocurre con Durán Martíniz o Fernán Pacho, también figuran en la nómina otros personajes en cuyo caso son sus lazos familiares los que nos hablan de una condición social no precisamente modesta, como dos hijos de Alfonso Portiella, quien durante buena parte del reinado de Alfonso X desempeñó el cargo de merino de los diferentes Merinos Mayores de Asturias; la viuda de García Martíniz, quien fuera mayordomo del concejo ovetense en la tierra del alfoz, también en época del Rey Sabio; o dos sobrinos de obispo. Otros consiguieron la exención precisamente gracias a contar con familiares en el cabildo, como ocurre con doña Ingnés, excusada por su sobrino, el canónigo Fernán Díaz; o con el racionero Johan Alfonso, que utiliza su facultad de nombrar dos excusados para librar de tributos a su padre Alfonso Fernándiz y a su hermano Johan Alfonso. En otros casos, aunque no son sus propios parientes quienes les excusan, es más que probable que este lazo familiar fuese determinante para obtener la exención, como puede suponerse para Giral Alfonso, sobrino del arcediano Bartolomé Pérez; Pedro Iohan, carnicero, padre del clérigo del coro Alfonso Pérez; o Rodrigo Yannes, hermano del canónigo Alfonso Yannes Arllós. Y algo parecido debió de ocurrir con los personajes que tenían vínculos clientelares con el clero, como Gonçalo Rodríguiz, criado y portero del obispo; Johan Peláiz, criado del chantre; o Lorienço Pérez de la Vinna, "omne" del arcediano de Gordón. Y, aunque desconozcamos los mecanismos utilizados para ello, puede detectarse incluso cómo algunas familias parecen haber conseguido crear verdaderas "dinastías de excusados", obteniendo exención para miembros de distintas generaciones: así, aparecen en la lista Martín Macanno y su hijo, el mercader Alfonso Martíniz; Alfonso Pérez y su hijo Johan Alfonso, ambos mercaderes; el mercader Pedro Miguélliz y su yerno, el zapatero Alfonso de Roças; o Sancho García, que ocupó repetidamente cargos concejiles, y su sobrino Sancho Pérez.

En definitiva: la encuesta prosopográfica ha desvelado que los temores y sospechas que hemos visto que albergaban los concejos sobre la posibilidad de que la figura de los excusados de la Iglesia fuese aprovechada para eximir de tributos a algunos de los vecinos más ricos e influyentes no eran infundados, al menos para el caso ovetense. Aunque no puede obviarse la importante presencia de menestrales en la nómina de excusados de la iglesia de Oviedo, resulta evidente que una parte destacada de la élite dirigente urbana encontró también abrigo en las exenciones fiscales que dispensaban las autoridades eclesiásticas. Esta conclusión, sin embargo, lejos de dejar cerrada la cuestión, abre nuevos interrogantes: ¿Cuáles fueron los procedimientos utilizados por los miembros de la élite para obtener la condición de excusados de la Iglesia? ¿Se trataba meramente de aprovechar los vínculos familiares y clientelares existentes, o pudo haber espacio para la venalidad y la compensación económica en la distribución aparentemente graciosa de exenciones por parte del clero capitular? ¿La condición de excusado era compatible con el ejercicio simultáneo de cargos concejiles? ¿Durante cuánto tiempo disfrutaba una misma persona de este tipo de exención? ¿Pudo utilizarse la condición de excusado para pasar a alcanzar la condición de privilegiado nato, especialmente en el caso de las "dinastías de excusados"? Y, sobre todo, ¿cómo reformular la 
historia de los enfrentamientos concejo-Iglesia a la luz de esta estrechísima asociación de intereses y personas? ${ }^{92}$

Aunque muchas de estas preguntas parecen tener difícil respuesta a la luz del estado actual de nuestros conocimientos y del tipo de informaciones que ofrece la documentación conservada, habrá que seguir trabajando en el estudio de los excusados de la Iglesia, un grupo social que quizá no ha recibido hasta el momento toda la atención que merece por parte de los historiadores de las sociedades urbanas de la Edad Media.

Tabla 1: Los excusados de la iglesia de Oviedo en $1301^{93}$

\begin{tabular}{|c|c|c|c|}
\hline NOMBRE & PROFESIÓN & CARGOS & OBSERVACIONES \\
\hline Aldonça Elías & & & $\begin{array}{c}\text { viuda de Martín } \\
\text { Iohannes, frenero }\end{array}$ \\
\hline Alfonso Fernándiz & $\begin{array}{c}\text { "luquetero" } \\
\text { (fabricante de } \\
\text { pestillos) }\end{array}$ & & $\begin{array}{c}\text { padre del racionero } \\
\text { Johan Alfonso, } \\
\text { que lo excusa, y de } \\
\text { Rodrigo Alfonso, } \\
\text { también excusado }\end{array}$ \\
\hline $\begin{array}{c}\text { Alfonso Fernándiz } \\
\text { diene un criado } \\
\text { dlamado Alfonso } \\
\text { Peláiz }\end{array}$ \\
\hline Alfonso Iohan & peletero & & sobrino del obispo \\
\hline Alfonso Martíniz & mercader & & \\
\hline Alfonso Martíniz & sastre & & \\
\hline
\end{tabular}

92. Por ejemplo, para Oviedo es bien conocido el feroz enfrentamiento que protagonizó Alfonso Nicolás con la mitra ovetense, el cual alcanzaría su fase más aguda durante el episcopado de Fernando Alfonso, que fallecería el 23 de octubre de 1301, quedando la sede vacante hasta mayo del año siguiente: Ruiz de la Peña Solar, "Alfonso Nicolás...”, op. cit., pp. 135-140. Y sin embargo, resulta especialmente chocante que en la nómina de excusados, que debió de redactarse precisamente siendo aún titular de la mitra el encarnizado enemigo de Alfonso Nicolás (se elaboró en 1301, sin precisar más la fecha, pero en ella figuran los excusados del obispo, por lo que resultaría extraño que se refiera al período de sede vacante), aparezcan, como hemos visto, numerosas personas del círculo de este personaje, hasta el punto de que su cuñada Taresa Alfonso de la Rúa es, incluso, excusada del propio obispo.

93. Sólo se incluyen aquellos excusados de los que ha sido posible obtener algún dato prosopográfico de interés: 115 de un total de 187. La frecuente aparición de varios excusados del mismo nombre en la lista no se trata de un error, sino que se debe a una fuerte presencia de la homonimia en la época, tal y como puede comprobarse en el documento original (vid. documento $\mathrm{n}^{\circ} 1$ del Apéndice Documental). Cuando algún dato es dudoso, se señala con un interrogante. 


\begin{tabular}{|c|c|c|c|}
\hline Alfonso Martíniz & mercader & & $\begin{array}{c}\text { hijo de Martín } \\
\text { Macanno, también } \\
\text { excusado }\end{array}$ \\
\hline $\begin{array}{c}\text { Alfonso Miguélliz } \\
\text { del Portal }\end{array}$ & $\begin{array}{c}\text { "alfageme" } \\
\text { (barbero), hortelano }\end{array}$ & & \\
\hline Alfonso Pérez & sastre & & \\
\hline Alfonso Pérez & mercader & & \\
\hline Alfonso Pérez & mercader & & $\begin{array}{l}\text { padre de Johan } \\
\text { Alfonso, mercader, } \\
\text { también excusado }\end{array}$ \\
\hline Alfonso Pérez & peletero & & $\begin{array}{l}\text { marido de Johanna } \\
\text { Pérez, panadera }\end{array}$ \\
\hline $\begin{array}{l}\text { Alfonso Pérez } \\
\text { Murcia }\end{array}$ & peletero & & \\
\hline $\begin{array}{l}\text { Alfonso Pérez de } \\
\text { Socastiello }\end{array}$ & mercader & & $\begin{array}{c}\text { sobrino de Pedro } \\
\text { Bretón, que fue juez } \\
\text { en } 1264 \text { y alcalde en } \\
1280\end{array}$ \\
\hline Alfonso de Roças & zapatero & & $\begin{array}{l}\text { yerno del mercader } \\
\text { Pedro Miguélliz, } \\
\text { también excusado }\end{array}$ \\
\hline Alfonso Rodríguiz & & $\begin{array}{c}\text { oficial del } \\
\text { cabildo (portero) }\end{array}$ & \\
\hline Alfonso Rodríguiz & mercader & & \\
\hline Alfonso Sánchiz & sastre & & \\
\hline Alfonso Suáriz & sastre & & $\begin{array}{l}\text { suegro del vainero } \\
\text { Pedro Iohan, también } \\
\text { excusado }\end{array}$ \\
\hline $\begin{array}{l}\text { Alfonso Yannes de } \\
\text { Trasantisso }\end{array}$ & cerrajero & & $\begin{array}{c}\text { realiza numerosas } \\
\text { compras en el } \\
\text { concejo de Llanera, } \\
\text { de donde procede; } \\
\text { prestamista }\end{array}$ \\
\hline Anrique & & $\begin{array}{l}\text { oficial del } \\
\text { cabildo } \\
\text { ("latinero") }\end{array}$ & \\
\hline $\begin{array}{l}\text { Apparicio } \\
\text { Fernándiz }\end{array}$ & & & $\begin{array}{l}\text { yerno de Alfonso } \\
\text { Nicolás, cambista y } \\
\text { alcalde del rey }\end{array}$ \\
\hline Bartolomé Alfonso & & $\begin{array}{c}\text { mandador del } \\
\text { concejo en } 1320 ; \\
\text { personero del } \\
\text { concejo en } 1332 ?\end{array}$ & \\
\hline Bartolomé Alfonso & tendero, cambista & $\begin{array}{l}\text { juez en } 1308, \\
1312 \text { y } 1317 ?\end{array}$ & \\
\hline $\begin{array}{l}\text { Bartolomé } \\
\text { Fernándiz }\end{array}$ & sastre & & \\
\hline
\end{tabular}




\begin{tabular}{|c|c|c|c|}
\hline $\begin{array}{c}\text { Bartolomé } \\
\text { Martíniz }\end{array}$ & peletero & & \\
\hline $\begin{array}{l}\text { Bartolomé Peláiz } \\
\text { de Socastiello }\end{array}$ & sastre & & \\
\hline Beneyta Pérez & tendera & & \\
\hline Diego Pérez & carnicero & & $\begin{array}{c}\text { hijo de Pedro Cayés, } \\
\text { carnicero }\end{array}$ \\
\hline Domingo Casielles & mercader & $\begin{array}{c}\text { personero } \\
\text { y fiador del } \\
\text { concejo en } 1308\end{array}$ & \\
\hline Domingo Iohan & hortelano & & \\
\hline $\begin{array}{c}\text { Domingo Iohan de } \\
\text { la Gasconna }\end{array}$ & mercader & & \\
\hline Domingo Peláiz & cuchillero & & \\
\hline Doyannes & vainero & & \\
\hline Durán Martíniz & cambista, tendero & $\begin{array}{l}\text { personero del } \\
\text { concejo en } \\
1312 \text { y } 1317 \text {; } \\
\text { juez en } 1315- \\
1316\end{array}$ & $\begin{array}{l}\text { tiene un criado } \\
\text { llamado Alvar Peláiz }\end{array}$ \\
\hline Estevan Nicolás & sastre & & \\
\hline Estevan Pérez & "sorgián" (cirujano) & & \\
\hline Estevan Pérez & zapatero & & \\
\hline Fernán Alfonso & sastre & & \\
\hline $\begin{array}{c}\text { Fernán Iohannes } \\
\text { de la Ferrería }\end{array}$ & mercader & & \\
\hline $\begin{array}{c}\text { Fernán Iohannes } \\
\text { de la Nozeda }\end{array}$ & mercader & & \\
\hline Fernán Monión & vainero & & \\
\hline Fernán Nicolás & tendero & $\begin{array}{c}\text { juez en } 1308 \text { y } \\
1328\end{array}$ & $\begin{array}{l}\text { hijo del tendero } \\
\text { Nicolao Guión; } \\
\text { fiador de Alfonso } \\
\text { Nicolás, cambista y } \\
\text { alcalde del rey }\end{array}$ \\
\hline Fernán Pacho & & $\begin{array}{c}\text { oficial del } \\
\text { cabildo } \\
\text { ("periguador"); } \\
\text { juez en } 1314 \text { y } \\
\text { 1324; uno de los } \\
\text { doce hombres } \\
\text { buenos dados por } \\
\text { el concejo en el } \\
\text { convenio con el } \\
\text { obispo en } 1314\end{array}$ & $\begin{array}{c}\text { tiene un "omne" } \\
\text { llamado Alfonso } \\
\text { Rodríguiz y un } \\
\text { criado llamado Juan } \\
\text { Díaz }\end{array}$ \\
\hline
\end{tabular}




\begin{tabular}{|c|c|c|c|}
\hline $\begin{array}{c}\text { Fernán Peláiz del } \\
\text { Portal } \\
\end{array}$ & mercader & & \\
\hline Fernán Perez & mercader & & \\
\hline Fernán Pérez & peletero & & \\
\hline Fernán Pérez & vainero & & \\
\hline $\begin{array}{c}\text { Fernán Pérez del } \\
\text { Rosal }\end{array}$ & mercader & & \\
\hline $\begin{array}{c}\text { Fernán Rodríguiz } \\
\text { del Portal }\end{array}$ & mercader & & \\
\hline García Fernándiz & & $\begin{array}{l}\text { oficial del } \\
\text { cabildo } \\
\text { ("escancián") }\end{array}$ & \\
\hline $\begin{array}{c}\text { García Fernándiz } \\
\text { de Socastiello }\end{array}$ & mercader, cambista & $\begin{array}{c}\text { jurado del } \\
\text { concejo en } 1300\end{array}$ & \\
\hline Giral Alfonso & mercader, peletero & & $\begin{array}{c}\text { sobrino del } \\
\text { arcediano Bartolomé } \\
\text { Pérez }\end{array}$ \\
\hline Gonçalo García & mercader, cambista & $\begin{array}{c}\text { oficial del } \\
\text { cabildo (portero) }\end{array}$ & $\begin{array}{l}\text { sobrino del obispo } \\
\text { Fernando III }\end{array}$ \\
\hline Gonçalo Rodríguiz & mercader, cambista & & $\begin{array}{l}\text { criado y portero del } \\
\text { obispo Fernando IV }\end{array}$ \\
\hline Guillén Pérez & tendero & $\begin{array}{c}\text { juez en } 1309- \\
1310 \text { y } 1318\end{array}$ & \\
\hline Gutier Alfonso & carnicero & & $\begin{array}{c}\text { hijo de Alfonso } \\
\text { Pérez, capellán de } \\
\text { San Pedro del Otero }\end{array}$ \\
\hline Ingnés, donna & & & $\begin{array}{l}\text { tía del canónigo } \\
\text { Fernán Díaz, que la } \\
\text { excusa }\end{array}$ \\
\hline Ingnés Fernándiz & cordonera & & \\
\hline Johan Alfonso & mercader & & $\begin{array}{l}\text { hijo de Alfonso } \\
\text { Pérez, mercader, } \\
\text { también excusado }\end{array}$ \\
\hline Johan Bartolomé & herrero & alcalde en 1312 & $\begin{array}{c}\text { funda un aniversario } \\
\text { en la catedral }\end{array}$ \\
\hline Johan Fernándiz & hortelano & & \\
\hline Johan Peláiz & & & criado del chantre \\
\hline Johan Pérez & cuchillero & & \\
\hline $\begin{array}{l}\text { Johan Pérez de } \\
\text { Trasantisso }\end{array}$ & cerrajero & & \\
\hline Johanna Iohannes & & & $\begin{array}{l}\text { esposa de Pedro } \\
\text { Iohannes, } \\
\text { "luquetero" } \\
\text { (fabricante de } \\
\text { pestillos) }\end{array}$ \\
\hline
\end{tabular}




\begin{tabular}{|c|c|c|c|}
\hline $\begin{array}{c}\text { Lorienço Pérez de } \\
\text { la Vinna }\end{array}$ & & & $\begin{array}{l}\text { “omne" del } \\
\text { arcediano de } \\
\text { Gordón; fiador del } \\
\text { canónigo Fernán } \\
\text { Fernándiz }\end{array}$ \\
\hline Luques Pérez & hortelano & & $\begin{array}{l}\text { su viuda funda un } \\
\text { aniversario por él } \\
\text { en la cofradía del } \\
\text { Rey Casto; tiene un } \\
\text { criado llamado Johan } \\
\text { Pérez, hortelano }\end{array}$ \\
\hline Luques Rodríguiz & cambista & $\begin{array}{l}\text { personero del } \\
\text { concejo en } 1300\end{array}$ & $\begin{array}{l}\text { yerno y tutor de } \\
\text { los hijos de Taresa } \\
\text { Alfonso de la Rúa, } \\
\text { también excusada }\end{array}$ \\
\hline Marcos, don & zapatero & & \\
\hline Marcos Martíniz & hortelano & & \\
\hline María Esídriz & & & $\begin{array}{c}\text { viuda de García } \\
\text { Martiniz, que fue } \\
\text { mayordomo en el } \\
\text { alfoz ovetense por el } \\
\text { concejo en época de } \\
\text { Alfonso X }\end{array}$ \\
\hline Martín Macanno & & & $\begin{array}{l}\text { padre del mercader } \\
\text { Alfonso Martíniz, } \\
\text { también excusado }\end{array}$ \\
\hline $\begin{array}{c}\text { Martín Peláiz de la } \\
\text { Ferrería }\end{array}$ & herrero & & \\
\hline Martín Pérez & $\begin{array}{c}\text { "luquetero" } \\
\text { (fabricante de } \\
\text { pestillos) }\end{array}$ & & \\
\hline $\begin{array}{c}\text { Martín Sánchiz de } \\
\text { la Rúa }\end{array}$ & mercader & & $\begin{array}{c}\text { funda un aniversario } \\
\text { en la cofradía del } \\
\text { Rey Casto; padre de } \\
\text { Gonzalo Martínez, } \\
\text { tendero } \\
\end{array}$ \\
\hline Mayor Alfonso & & & $\begin{array}{l}\text { hija de Alfonso } \\
\text { Portiella, merino del } \\
\text { Merino Mayor de } \\
\text { Asturias en época de } \\
\text { Alfonso X; hermana } \\
\text { de Rodrigo Alfonso, } \\
\text { también excusado }\end{array}$ \\
\hline Nicolao Franco & zapatero & & \\
\hline $\begin{array}{l}\text { Nicolao Iohannes } \\
\text { del Rosal }\end{array}$ & carpintero & & $\begin{array}{c}\text { dicta sentencia } \\
\text { arbitral en un } \\
\text { pleito acerca de la } \\
\text { construcción de unas } \\
\text { casas }\end{array}$ \\
\hline
\end{tabular}




\begin{tabular}{|c|c|c|c|}
\hline Nicolao Martíniz & sastre & & \\
\hline Nicolao Pérez & alberguero & & \\
\hline Pasqual Iohannes & $\begin{array}{c}\text { "luquetero" } \\
\text { (fabricante de } \\
\text { pestillos) }\end{array}$ & & \\
\hline Pedro Alfonso & mercader & & \\
\hline Pedro Alfonso & sastre & & \\
\hline Pedro Bono & mercader, cambista & $\begin{array}{c}\text { mandador del } \\
\text { concejo en 1320; } \\
\text { uno de los doce } \\
\text { hombres buenos } \\
\text { dados por el } \\
\text { concejo en la } \\
\text { avenencia con el } \\
\text { obispo de } 1314\end{array}$ & \\
\hline Pedro Cano & vainero & & \\
\hline Pedro Franco & tendero, mercader & $\begin{array}{l}\text { juez en } 1312 ; \\
\text { uno de los doce } \\
\text { hombres buenos } \\
\text { dados por el } \\
\text { concejo en la } \\
\text { avenencia con el } \\
\text { obispo de } 1314\end{array}$ & $\begin{array}{l}\text { tiene un criado } \\
\text { llamado Suer } \\
\text { Pérez; custodiaba } \\
\text { en su casa "diez } \\
\text { varas de camellín" } \\
\text { del maestrescuela } \\
\text { Rodrigo Díez; fiador } \\
\text { de Alfonso Nicolás, } \\
\text { cambista y alcalde } \\
\text { del rey, y tutor de su } \\
\text { hijo Johan Alfonso, } \\
\text { que será racionero } \\
\end{array}$ \\
\hline Pedro Geráldiz & tendero, cambista & & \\
\hline Pedro Infante & carnicero & & \\
\hline Pedro Iohan & carnicero & & $\begin{array}{l}\text { padre de Alfonso } \\
\text { Pérez, clérigo del } \\
\text { coro }\end{array}$ \\
\hline Pedro Iohan & hortelano & & \\
\hline Pedro Iohan & orfebre & & \\
\hline Pedro Iohan & vainero & & $\begin{array}{l}\text { yerno del sastre } \\
\text { Alfonso Suáriz, } \\
\text { también excusado }\end{array}$ \\
\hline Pedro Iohan & vainero & & \\
\hline $\begin{array}{l}\text { Pedro Iohan de la } \\
\text { Gasconna }\end{array}$ & sastre & & \\
\hline $\begin{array}{l}\text { Pedro Iohan de la } \\
\text { Rúa }\end{array}$ & tendero & $\begin{array}{c}\text { personero } \\
\text { y fiador del } \\
\text { concejo en } 1308\end{array}$ & \\
\hline
\end{tabular}




\begin{tabular}{|c|c|c|c|}
\hline Pedro Martíniz & orfebre, tendero & alcalde en 1314 & \\
\hline Pedro Miguélliz & mercader & & $\begin{array}{l}\text { suegro del zapatero } \\
\text { Alfonso de Roças, } \\
\text { también excusado; } \\
\text { tenía una comuña } \\
\text { con el maestrescuela } \\
\text { Rodrigo Díez en } \\
\text { Soconco }\end{array}$ \\
\hline Pedro Sánchiz & vainero & & \\
\hline Peley Alfonso & arriero & & \\
\hline Rodrigo Alfonso & & & $\begin{array}{c}\text { hermano del } \\
\text { racionero Johan } \\
\text { Alfonso, que lo } \\
\text { excusa; hijo de } \\
\text { Alfonso Fernándiz, } \\
\text { también excusado }\end{array}$ \\
\hline Rodrigo Alfonso & & & $\begin{array}{c}\text { hijo de Alfonso } \\
\text { Portiella, que fue } \\
\text { merino del Merino } \\
\text { Mayor de Asturias en } \\
\text { época de Alfonso X; } \\
\text { hermano de Mayor } \\
\text { Alfonso, también } \\
\text { excusada }\end{array}$ \\
\hline Rodrigo Rodríguiz & mercader & & \\
\hline Rodrigo Yannes & & & $\begin{array}{l}\text { hermano del } \\
\text { canónigo Alfonso } \\
\text { Yannes Arllós }\end{array}$ \\
\hline $\begin{array}{c}\text { Roy Iohannes del } \\
\text { Portal }\end{array}$ & cambista & & \\
\hline Roy Martíniz & peletero & & \\
\hline Roy Pérez & & $\begin{array}{c}\text { oficial del } \\
\text { cabildo ("trae la } \\
\text { agua") }\end{array}$ & \\
\hline Sancho García & & $\begin{array}{c}\text { juez en } 1289 \text { y } \\
\text { 1308; alcalde en } \\
\text { 1314; alcalde del } \\
\text { rey en 1308, } 1309 \\
\text { y 1324; árbitro } \\
\text { nombrado por el } \\
\text { concejo en el pleito } \\
\text { con el obispo de } \\
\text { 1308; uno de los } \\
\text { doce hombres } \\
\text { buenos dados por } \\
\text { el concejo en la } \\
\text { avenencia con el } \\
\text { obispo de } 1314\end{array}$ & $\begin{array}{l}\text { tío de Sancho Pérez, } \\
\text { también excusado }\end{array}$ \\
\hline
\end{tabular}




\begin{tabular}{|c|c|c|c|}
\hline Sancho Geráldiz & cambista & & \\
\hline $\begin{array}{c}\text { Sancho Iohannes } \\
\text { del Portal }\end{array}$ & cambista & & $\begin{array}{c}\text { sobrino de Sancho } \\
\text { García, juez y } \\
\text { alcalde, también } \\
\text { excusado }\end{array}$ \\
\hline Sancho Pérez & & & \\
\hline Suer Fernándiz & sastre & & $\begin{array}{c}\text { vernán Nicolás; } \\
\text { cuñada de Alfonso } \\
\text { Nicolás, cambista } \\
\text { (cacharrero) }\end{array}$ \\
\hline $\begin{array}{c}\text { Taresa Alfonso de del rey; } \\
\text { la Rúa }\end{array}$ & & & $\begin{array}{c}\text { suegra del cambista } \\
\text { Luques Rodríguiz, } \\
\text { también excusado }\end{array}$ \\
\hline
\end{tabular}

\section{ApÉNDICE DOCUMENTAL}

\section{1. [Oviedo].}

Lista de los excusados del obispo y el cabildo de la catedral de Oviedo.

A.- Pergamino, $28 \times 51 \mathrm{~cm}$. Manchas de humedad que han diluido la tinta en algunas partes. Dos agujeros para sello pendiente.

ACO, Pergaminos, Serie B, carp. 6, $n^{\circ} 11$.

REG.: García Larragueta, Catálogo, no 564, pp. 196-7.

CIT.: Fernández Conde, La clerecía ovetense, p. 17; Suárez Beltrán, El cabildo de la catedral, pp. 55, 59, 273-4 у 277.

Era $\mathrm{M}^{\mathrm{a}} \mathrm{CCC}^{\mathrm{a}}$ XXXVIIII'. Estos son los escusados que da el obispo e la eglesia de Oviedo:

Estos son los escusados del obispo: Alfonso Pérez del Campo. So fillo Bartolomé Alfonso. Pedro Alfonso de Trasantisso. Pedro Martíniz, oriz. Pedro García, marido de María Garín. Bartolomé Martíniz, pellitero. Alvar Pérez de Trasantisso. Pasqual Iohannes. Mestre Domingo. Gonçalo Rodríguiz, marido de Ingnés Pérez. Alfonso Pérez, pellitero, marido de Johanna Pérez, panadera. Fernán Alfonso, gienro de Pedro García Garín. Taresa Alfonso de la Rúa. García Fernándiz de Socastiello, mercador. E Fernán Martíniz del Rosal.

Del deán: Loba Domínguiz. Fernán Pérez, vaynero. Rodrigo Yannes, hermano de Alfonso Yannes Arllós. María Esídriz, muller que foe de García Martíniz. Domingo Fernándiz, [di]cho Verinna. Alfonso Pérez, alfayate. 
Del archediano mestre Iohan Miguélliz: Luques Rodríguiz. Martín Peláiz de la Ferrería. Pedro Infante. E Alfonso Iohan, pellitero, morador en Barredo.

Del archediano Martín Lópiz: [... $]^{94}$. Donna María Fernándiz, muller que foe de Fernán Iohannes Baldorión. Alfonso Pérez, mercador, gienro de Alfonso Domínguiz. E María Fernándiz, muller que foe de Alfonso Martíniz de la [...]uz.

Del archediano Bartolomé Pérez: Fernán [N]icolás. Rodrigo Alfonso, fillo de Alfonso Portiella. Martín Cuerdo. E María Geráldiz, filla de Giral Pérez.

Del archediano don Gaofrido: Fernán Iohannes, frenero. Peley Alfonso, andador de bestias. Johan Domínguiz del Pevidal. E Marcos Martíniz, ortolano.

Del archediano Gonçalo García: Domingo Pérez S[...]s. Lorienço Pérez de la Vinna. Mayor Alfonso de la Rúa. E Gutier Yannes de Barredo.

Del archediano don Jacob: Pedro Miguélliz, mercador, e so gienro Alfonso de Roças, çapatero. Fernán Pérez, mercador, morador a la Çogue. Pedro Cano, vaynero.

Del archediano de Tineo: Alfonso Rodríguiz de la Gasconna. Guillén Perez. Nicolao Rodríguiz del Rosal. E Alvar García de Socastiello.

Del thesorero: Mayor Pérez de la Çogue. Aparicio de la Nuzeda. Johan Pérez, cuchellero, morador al canto de la Ferrería. E Pedro Iohan, vaynero, gienro de Alfonso Suáriz.

Del mestrescolas: Alfonso Sánchiz de Socastiello. Pedro Iohan, ortolano. Pedro Alfonso, fillo de Alfons d'Espanna. Johan Alfonso del Rosal.

Del chantre: Alfonso Pérez, mercador, e so fillo Johan Alfonso. María Iohan, filla de Johan Ampolla. E Nicolao Pérez, alberguero.

De mestre Álvaro: Durán Martíniz e Roy Iohannes del Portal.

De Sancho Ramíliz: Fernán Peláiz de la Rúa e Apparicio Fernándiz.

De Alfonso Yannes Arllós: Alfonso Miguélliz del Portal e Alfonso Yannes de Trasantisso, marido de Johanna Micolás ${ }^{95}$.

De don Pedro d'Altas Vinnas: Fernán Iohannes de la Nozeda e Johan de Nadio.

De mestre G[onça]lo: Alfonso Fernándiz de la Rúa e Taresa Iohannes de Trasantisso.

De Rodrigo Álvariz: Pedro Franco e Roy Fernándiz de Cimadevilla.

De Johan Iohannes: Martín Domínguiz de la Rúa e Alfonso Martíniz, fillo de Martín Macanno.

De don James: Pedro Iohan, vaynero, e Nicolao Franco, çapatero.

De Alfonso Yannes Obispo: Fernán Iohannes de la Ferrería e Martín Alfonso.

De Elías Rosiello: Sancho García e so sobrión Sancho Pérez.

De Pedro Amigo: Alfonso Pérez Murcia e Aldonça Elías, muller que foe de Martín Iohannes, frenero.

De don Vidal: Fernán Pérez del Rosal, mercador, e María García de Barredo.

De Fernán Álvariz: Alvar Rodríguiz de la Rúa e Alfons de Perullera.

De Roy Gonçáliz: Sancho Geráldiz e Pedro Geráldiz, cambiador.

De Alfonso Yannes d'Astorga: Fernán Peláiz del Portal, mercador, e Pedro Iohan, oriz.

De Fernán Rodríguiz: Alfonso [... $]^{96}$ fillo de $[\ldots]^{97}$. Alfonso Pérez, criado de Fernán Geráldiz.

De Gonçalo Rodríguiz: Alfonso Pérez Canzienes e Fernán Rodríguiz del Portal.

De Domingo Pérez: Estevan Pérez, sorgián, e Luques Pérez, ortolano.

94. El nombre del primer excusado fue raspado en el pergamino.

95. Sic pro Nicolás.

96. Raspado.

97. Raspado. 
De Rodrigo Rodríguiz: Pedro Alfonso, fillo de Alfonso Loriénciz, e Alfonso Fernándiz, luquetero.

De Alfonso Pérez: Nicolao Pérez, marido de Sancha Rodríguiz, e Sancha Alfonso, muller que foe del Lobeto.

De García Gonçáliz Quilós: Domingo Casielles e Bartolomé Peláiz de Socastiello, alfayate.

De mestre Gil: Martín Pérez, luquetero, e Johanna Iohannes, muller de Pedro Iohannes, luquetero.

De Pedro Gonçáliz Castroxoriz ${ }^{98}$ : Lorienço Pérez de Trasantisso e Alfonso Pérez de Socastiello, mercador, sobrión de don Pedro Bretón.

De Alfonso Loriénciz: Estevan Nicolás, alfayate, e Alfonso García de Cimadevilla, fillo de donna Olalla.

De Martín Fernándiz: Alfonso Suáriz, alfayate, e don Marcos, morador enna Rúa de los Albergueros.

De Pedro Iohan: Fernán Pérez, pellitero, marido de Sancha Alfonso, e Alfonso Martíniz Boca'l Tonel.

De mestre Suero: Alfonso Yannes, marido de María Leona, e Gutier Alfonso, carniçero.

De Gutier Gonçáliz: Alfonso Peláiz del Campo e Pedro Alfonso, mercador, que muera dientro la puerta de Socastiello.

De Gómez Pérez: Pedro Sánchiz, vaynero, e Bartolomé Fernándiz, alfayate.

De Martín Rodríguiz: Roy Martíniz,pellitero, morador enna Nozeda, e Roy Pérez de Socastiello.

De García Pérez: Giral Alfonso e Martín Sánchiz de la Rúa.

De Johan Macías: Pedro Iohan de la Rúa e Sancho Iohannes del Portal.

De Alfonso Thomás: Bartolomé Alfonso, tendero, e $<$ Domingo Peláiz, cuchellero $>99$.

De don Beltrán: Marinna Díaz de la Vinna e Nicolao Iohannes de Latores.

De Pedro Fernándiz: Pedro Iohan, alfayate de la Gasconna, e Estevan Pérez, çapatero.

De Apparicio Martíniz: Pedro Alfonso del Portal e Domingo Iohan, ortolano.

De Fernán Díaz: donna Ingnés, sua tía, e Johan Peláiz, criado del chantre.

De Alvar Gonçáliz: Pedro Iohan, carnicero, e Alfonso Pérez de Faro.

De Fernán Bretón: María Bartolomé de Trasantisso e Pedro Alfonso, alfayate.

De Roy Lópiz: Domingo Iohan, marido de María Mossagro, e Johan Bartolomé, ferrador.

De Roy Suáriz: Pedro Bono, mercador, e Doyannes, vaynero.

De Miguel Rodríguiz: Johan Pérez, sarrallero de Trasantisso, marido de Aldonça Martíniz, e Pedro Martíniz de Sant Cloyo, morador en Casa Sola.

De García Gonçáliz: Alfonso Yannes Armalla e Nicolao Iohannes del Rosal, carpentero.

De Pedro Martíniz d'Astorga: Domingo Iohan de la Gasconna, mercador, e Mayor Bartolomé.

De Suer Gonçáliz: Suer Pérez, cachero, e Fernán Monión, vaynero.

De mestre Pedro Cosme: Mayor Pérez de la Buéveda e Orraca Alfonso de Barredo.

De Johan Alfonso: Alfonso Fernándiz, so padre, e so fillo Rodrigo Alfonso.

De Diego Suáriz: Roy Pérez, fillo de Pedro Alfonso del Portal, e Mayor Alfonso, filla de Alfonso Portiella.

De Pedro Díaz: Suer Fernándiz e Alfonso Martíniz, alfayates.

98. Sic pro Castroxeriz.

99. El nombre original del segundo excusado fue raspado en el pergamino, sobrescribiéndose Domingo Peláiz, cuchellero. 
De Roy Martíniz: Fernán Alfonso, fillo de Alfonso Carrenno, e Johan Alfonso del Rosal.

De Pedro Rodríguiz Agüera: Domingo Ricavo de la Ferrería e Alfonso Martíniz, mercador, morador en Socastiello.

De Miguel Fernándiz: Diego Pérez, fillo de Pedro Cayés, e D[... $]^{100}$.

De Roy García: Alfonso Rodríguiz, mercador, morador fuera la cerca, [e B]eneyta Pérez, tendera.

De Alfonso Peláiz: Alfonso Sánchiz, alfayate, e Martín Iohan, balestero.

De mestre Pedro: Martín Macanno e Rodrigo Rodríguiz, mercador.

De Menén Martíniz: Alfonso Barquero e Nicolao Pérez Eruga.

De Menén Gonçáliz: Johan Fernándiz, ortolano, e Nicolao Martíniz, alfayate.

De Díe Díaz: Fernán Alfonso, alfayate, e Alfonso Amariello.

De Fernán Suáriz: Alfonso Nicolás de Faro e Ingnés Fernándiz, gordonera.

De Johan Díaz ${ }^{101}$ : Adam Pérez de Cimadevilla e Johan Pasquáliz.

Officiales:

Gonçalo García, portero.

Alfonso Rodríguiz, portero.

Fernán Pacho, periguador.

Roy Pérez, que trae la agua.

García Fernándiz, escancián.

Anrique, latinero.

\section{1, septiembre, 28. Segovia.}

Alfonso XI, en respuesta a la queja de los cogedores de la fonsadera del año 1330, ordena a los concejos y autoridades de la ciudad de León y del valle de Torío que obliguen a contribuir en el pago de la fonsadera a todos los que se niegan a ello alegando estar exentos, a pesar de no tener los privilegios y cartas mencionados en la carta real para la recaudación.

B.- Pergamino, 46 x $61 \mathrm{~cm}$. Sentencia dada en León por los jueces del rey en dicha ciudad el 17 de diciembre de 1331, la cual inserta el documento. El original se describe como "una carta de nuestro sennor el rey don Alfonso escripta en papel e seellada con so seello".

ACL, doc. $n^{\circ} 6298$.

C.- Copia simple de $B$, del siglo $\mathrm{XV}^{102}$.

ACL, cód. 40, f. 210r.

REG.: Martín Fuertes, Colección documental XI (1301-1350), nº 2989, p. 356.

Сाт.: Santamarta Luengos, "Fiscalidad regia en León”, p. 503.

100. Raspado.

101. Respeto la separación que divide a este personaje de los anteriores en el manuscrito, si bien lo más probable es que se trate también de un racionero.

102. Editamos el texto de $C$. 
Don Alfonso, por la graçia de Dios rey de Castilla, de León, de Toledo, de Gallizia, de Sevilla, de Córdova, de Murçia, de Jahén e del Algarbe, e sennor de Vizcaya e de Molina, al conçejo e a los juyzes e a los alcaldes de la çibdat de León e de Val de Torío e a qualesquier o a qualquier de vos que esta mi carta vierdes, salud e graçia.

Sepades que los mis cogedores de la fonsadera que me ovistes a dar este anno que agora passó de la era de mill e trezientos e sesenta e ocho annos se me enbiaron querellar e dizen que ay algunos omes que se llaman escusados de las iglesias e de los abbadengos, e otrossí fijosdalgo e monederas ${ }^{103} \mathrm{e}$ amos de fijosdalgo, e que non quesieron nin quieren pagar los maravedís que montan en la dicha fonsadera non aviendo tales previllejos nin cartas commo en la mi carta de la cogetera se continen ${ }^{104}$ por que devan ser quitos de non pagar fonsadera. E pero que vos mostraron la dicha mi carta de la cogeta por muchas vezes que la non quesistes nin queredes conplir. E por esta razón que non pueden coger nin recabdar los maravedís que montan en la dicha fonsadera para los pagar a los mios vassallos a quien los yo y libré por mis cartas e que han perdido e menoscabado mucho de lo suyo. E enbiaron me pedir merçed que mandasse ay lo que toviesse por bien. E si esto así es soy ende maravillado en commo sodes osados de lo fazer assí.

Por que vos mando luego vista esta mi carta que fagades estos escusados sobredichos que la quantía ovieren si son enpadronados o fallardes por la pesquisa que fuer fecha que an las quantías para pagar la dicha fonsadera o que los mis cogedores abonaren que paguen la dicha fonsadera a los dichos mis cogedores. E si lo fazer non quesieren tomadles e prindadles lo que lles fallardes fasta en lo que cada uno oviere a pagar en la dicha fonsadera. E dadlo e entregadlo luego a los mis cogedores, salvo ende si ovieren tales previllejos o cartas commo en la mi carta de la cogeta se contiene. E vos nin ellos non fagades ende ál por alguna manera so pena de çient maravedís de la bona moneda cada uno, e de cómmo vos esta mi carta fuer mostrada e de cómmo la conplierdes mando a qualquier notario público que para esto fuer llamado que dee ende a los mis cogedores o al que vos esta mi carta mostrar testimonio signnado con so signno por que yo sepa cómo ${ }^{105}$ conplides mio mandado, e non faga ende ál so la dicha pena. La carta leyda dádgela.

Dada en Segovia, veynte e ocho días de setienbre, era de mill e trezientos e sesenta e nueve annos.

Yo Pero Ferrández la fize escrevir por mandado del rey. Ruy Martínez. Pero Ferrández.

\section{5, mayo, 6. Guadalajara.}

Pedro I confirma al obispo y cabildo de la iglesia Oviedo el privilegio de Alfonso X que concedía al obispo 15 excusados, 6 al deán, 4 a cada dignidad, 2 a cada canónigo o racionero y 1 a cada servicial, de acuerdo con el resultado favorable de la pesquisa realizada para suplir la falta de confirmación del privilegio por Alfonso XI.

B.- Pergamino, $27^{\prime} 5 \times 40 \mathrm{~cm}$. Es traslado notarial sacado en Oviedo con autorización judicial el 21 de octubre de 1355 por Juan Fernández, notario del rey en Oviedo, a petición del racionero Alvar González de Muros, procurador del cabildo ovetense. El original se

103. Sic pro monederos.

104. Sic pro contienen.

105. Sic pro cómmo. 
describe como "una carta de nuestro sennor el rey escripta en papel e sellada con su sello mayor en las espaldas".

ACO, Pergaminos, Serie A, carp. 20, nº 9.

EDIT.: Díaz Martín, Los origenes de la Audiencia, nº 67, pp. 129-131; Díaz Martín, Colección Documental de Pedro I, vol. III, no 930, pp. 257-8.

REG.: García Larragueta, Catálogo, $\mathrm{n}^{\circ} 753$, p. 258; Díaz Martín, Itinerario de Pedro I, ${ }^{\circ}$ 643, p. 330; Ladero Quesada, Fiscalidad y poder real, p. 357, nº 142.

CIT.: Fernández Conde, La clerecía ovetense, p. 17; Suárez Beltrán, El cabildo de la catedral, p. 277.

Don Pedro, por la graçia de Dios rey de Castiella, de León, de Toledo, de Gallizia, de Sevilla, de Córdova, de Murçia, de Iahén, del Algarbe, de Algezira, e sennor de Molina, al conçeio e a los alcalles e al juyz de la çibdat de Oviedo e al adelantado que por mí andodiere en las merindades de tierra de León e de Asturias, e al meryno o merynos que por mí o por él andodieren agora e d'aquí adelante, e a qualquier o a qualesquier de vos que esta mi carta fuer mostrada o el trasllado d'ella signado de escrivano público sacado con octuridat ${ }^{106}$ de juyz o de alcalle, salut e graçia.

Sepades que paresçeó ante los oydores de la mía audiençia el procurador de don Sancho, obispo de y de la dicha çibdat, e mostró ant'ellos una mi carta escripta en pargamino de cuero e sellada con mio sello de plommo en que se contenía qu'el rey don Alfonso, mio trasvisavuelo, por fazer bien e merçet a la eglesia de Oviedo, que mandó que el obispo que y fuesse e las perssonas e los canónigos que oviesen sus escusados assí commo los ovieran en tienpo del rey don Alfonso, su avuelo, e del rey don Fernando, su padre. E por razón que en las cortes que yo fize en Valladolid foe trayda esta dicha carta para que la mandase confirmar e gardar, e por que non apparesçía confirmaçión del rey don Alfonso, mio padre, que Dios perdone, fue fallado en la mi audiençia qu'el obispo e el deán e el cabillo devían a provar si usaran de la dicha carta e si les fuera gardada. E fue fecha pesquisa sobr'esta razón por mi carta e fue fallado por la dicha pesquisa qu'el dicho obispo e las otras perssonas e canónigos de la dicha eglesia que avían de aver estos escusados que se siguem ${ }^{107}$ : el obispo quinze escusados, e el deán seys escusados, e cada una de las perssonas de la dicha eglesia quatro escusados, e cada uno de los canónigos e conpanneros de la dicha eglesia dos escusados, e los serviçiales dende cada uno un escusado. E estos escusados que eran quitos de moneda e de serviçio cada que los echavan por la tierra, según que todo esto mellor e más conplidamientre se contién en la dicha mi carta. E agora diz que los cogedores que cogen e recabdan los dichos pechos que le non quieren guardar la dicha mi carta nin los dichos escusados e en esto que resçiben agravio e danno, e pedió a los dichos mis oydores que le mandassen dar mi carta por que les fuese gardado, e ellos mandáronle dar ende esta mi carta.

Por que vos mando, vista esta mi carta o el trasllado d'ella signado, commo dicho es, que guardedes e fagades guardar e conplir la dicha mi carta al dicho obispo e deán e cabillo e canónigos e los otros contenidos en ella bien e conplidamientre según que se en ella contién. E non prindedes nin consintades a ningún cogedor nin sobrecogedor nin a otro alguno que prinden nin tomen ninguna cosa de lo suyo a los dichos sus escusados que en la dicha mi carta se contienen que han de aver, commo dicho es, por los dichos pechos nin por alguno d'ellos, e si alguna cosa por esta razón les avedes o an tomado o prindado que ge lo fagades dar e tomar luego todo bien e conplidamientre en guisa que les non mengüe ende ninguna cosa. E los unos nin los otros non fagades ende ál por ninguna manera, so pena

106. Sic.

107. Sic pro siguen. 
de la mi merçet e de seyçientos maravedís desta moneda usual a cada uno. E demaes, por qualquier o qualesquier de vos por quien fincar de lo así conplir, mando al omne que vos esta mi carta mostrare que vos enplaze que parescades ante mí, do quier que yo sea, del día que vos enplazare a quinze días, so la dicha pena de los seyçientos maravedís a cada uno de vos, a dizer por quál razón non conplides mio mandado. E de cómmo vos esta mi carta fuere mostrada o el trasllado d'ella signado commo dicho es e la conplirdes, mando a qualquier escrivano público que para esto fuer llamado que dé ende al que vos la mostrar testimonio signado con su signno por que yo sepa en cómmo conplides mio mandado, e non faga ende ál so la dicha pena. La carta leyda dátgela.

Dada en Guadalfaiara, seys días de mayo, era de mille e trezientos e noventa e tres annos.

Gómez Ferrández, alcalle del rey e su chançeller, la mandó dar porque fue así librado en ela audiençia. Yo Diego Ferrández, escrivano del rey, la fiz escrevir por su mandado. Johan Sánchez, vista. Gómez Ferrández.

\section{0, agosto, 1. Sevilla.}

Enrique II ordena al concejo y autoridades de la ciudad de León que respeten los privilegios y cartas que Alfonso XI y los reyes anteriores habian otorgado a la iglesia de León para que tuviese excusados exentos de pecho, los cuales eran quebrantados por el concejo.

A.- Papel, 25 x $20 \mathrm{~cm}$. Sello de placa.

ACL, doc. $n^{\circ} 1230$.

REG.: García Villada, Catálogo, no 1230, p. 152; Álvarez Álvarez, Colección documental XII (1351-1474), no 3204, p. 49.

Don Enrique, por la graçia de Dios rey de Castilla, de León, de Toledo, de Gallizia, de Sevilla, de Córdova, de Murçia, de Jahén, del Algarbe, de Algezira, sennor de Molina, al conçeio e juezes e alcalles e omes bonos de la çibdat de León o a qualquier o a qualesquier de vos que esta nuestra carta vierdes o el traslado d'ella signado de escrivano público, salut e graçia.

Sepades que el obispo e deán e cabillo de la eglesia de León se nos enbiaron querellar e dizen que ellos que an previllejos e cartas del rey don Alfonso, nuestro padre, que Dios perdone, e de los otros reyes onde nos venimos, en que se contién que ayan sus escusados quitos de pecho, e que vos el dicho conçeio que les quebrantades los dichos previllejos e cartas e que ge las non queredes guardar, e les ydes e pasades contra ellos, e que en esto que resçiben muy grant agravio. E enbiaron nos pedir merçed que mandásemos sobr'ello lo que la nuestra merçed fuese.

Por que vos mandamos, vista esta nuestra carta o el traslado d'ella signnado commo dicho es, a todos e a cada unos ${ }^{108}$ de vos, que veades los dichos previllejos e cartas que los dichos obispo e cabillo o qualesquier d'ellos vos mostraren del dicho rey nuestro padre e de los otros reyes onde nos benimos, o los traslados d'ellos signnados de escrivanos públicos, e conplítgelos e fazétgelos guardar e conplir en todo segunt que en ellos se contién, e segunt que mejor e más conplidamente les fueron guardados en el tienpo del dicho rey nuestro padre, so las penas que en ellos se contienen. E los unos nin los otros non fagades ende ál

108. Sic pro uno. 
por ninguna manera, so pena de la nuestra merçed e de seyçientos maravedís desta moneda usal ${ }^{109}$ a cada uno de vos. Si non, por qualquier o qualesquier de vos por quien fincar de lo así fazer e conplir, mandamos al omne que vos esta nuestra carta mostrar que vos enplaze que parescades ante nos, el conçeio por vuestro personero e uno o dos de los ofiçiales personalmente con personería de los otros, del día que vos enplaziare a quinze días, so la dicha pena a cada uno, a dezir por qual razón non conplides nuestro mandado. E de cómmo esta nuestra carta vos fuer mostrada e los unos e los otros la conplierdes mandamos so la dicha pena a qualquier escrivano público que para esto fuer llamado que dé ende al que vos la mostrar testimonio signado con su signno, por que nos sepamos en cómmo conplides nuestro mandado. La carta leyda dátgela.

Dada en la muy noble çibdat de Sevilla, primero día de agosto, era de mill e quatroçientos e ocho annos.

Yo Johan Sánchez la fiz escrevir por mandado del rey. Vista.

\section{BIBLIOGRAFÍA}

Álvarez Álvarez, C. Colección documental del Archivo de la Catedral de León, XII (1351-1474), León, 1995.

Arranz Guzmán, A. "Los enfrentamientos entre concejos y poderes eclesiásticos en las cortes castellanas: ¿sincronización de los conflictos?”, Hispania, 171 (1989), pp. 5-68.

- "Clérigos y laicos en las cortes castellano-leonesas: la conflictividad como hilo conductor”, en El reino de León en la Alta Edad Media, IX, León, 1997, pp. 635-717.

- "Pedro I ante los enfrentamientos entre concejos y prelados castellanos", Anuario de Estudios Medievales, 30/1 (2000), pp. 235-275.

Cabeza Rodríguez, A. “Grupos excluidos y formas de asimilación y reproducción social. El ejemplo de la catedral de Palencia en la época moderna”, en Hernández Franco, J. (ed.). Familia y poder. Sistemas de reproducción social en España (siglos XVI-XVIII), Murcia, 1995, pp. 101-126.

Cal Pardo, E. Episcopologio Mindoniense, Santiago de Compostela, 2003.

Carande, R. "El obispo, el concejo y los regidores de Palencia (1352-1422). Aportación documental sobre el gobierno de una ciudad en la Edad Media", en Siete estudios de Historia de España, Barcelona, 1969, pp. 55-93.

Caso Fernández, F. de. Colección documental sobre la catedral de Oviedo, I (1300-1520), Gijón, 1982.

Cavero Domínguez, G., Álvarez Álvarez, C. y Martín Fuertes, J.A. Colección documental del Archivo Diocesano de Astorga, León, 2001.

Cavero Domínguez, G. y Domínguez Sánchez, S. Colección documental de la catedral de Astorga, III (1300-1499), León, 2000.

Cavero Domínguez, G. y Martín López, E. Colección documental de la catedral de Astorga, I (646-1126), León, 1999.

109. Sic pro usual. 
-. Colección documental de la catedral de Astorga, II (1126-1299), León, 2000.

Collantes de Terán, A. y Menjot, D. "Hacienda y fiscalidad concejiles en la Corona de Castilla en la Edad Media”, Historia. Instituciones. Documentos, 23 (1996), pp. 213-254.

Coria Colino, J.I. "La eliminación de los jueces de la Iglesia en los concejos medievales de la Corona de Castilla (s. XIII-XIV: León, Zamora, Salamanca y Murcia)", en Medievo hispano: estudios in memoriam del Prof. Derek W. Lomax, Madrid, 1995, pp. 111-119.

—. "La ciudad de Palencia de finales del siglo XII hasta la mitad del siglo XIII: organización municipal”, en Aniz Iriarte, C. y Díaz Martín, L. V. (coords.). Santo Domingo de Caleruega: contexto cultural. III Jornadas de Estudios Medievales, Salamanca, 1995, pp. 197-256.

Díaz Ibáñez, J. "Monarquía y conflictos Iglesia-concejos en la Castilla bajomedieval. El caso del obispado de Cuenca (1280-1406)", En la España Medieval, 17 (1994), pp. 133-156.

-. Iglesia, sociedad y poder en Castilla. El obispado de Cuenca en la Edad Media (siglos XII-XV), Cuenca, 2003.

Díaz Martín, L.V. Itinerario de Pedro I de Castilla. Estudio y regesta, Valladolid, 1975.

-. Los orígenes de la Audiencia Real Castellana, Sevilla, 1997.

-. Colección Documental de Pedro I de Castilla, 1350-1369, 4 vols., Salamanca, 1997-1999.

Esteban Recio, A. Palencia a fines de la Edad Media. Una ciudad de señorío episcopal, Valladolid, 1989.

Estepa Díez, C. Estructura social de la ciudad de León (siglos XI-XIII), León, 1977.

Fernández Conde, F.J. Gutierre de Toledo, obispo de Oviedo (1377-1389). Reforma eclesiástica en la Asturias bajomedieval, Oviedo, 1978.

- La clerecía ovetense en la Baja Edad Media. Estudio socioeconómico, Oviedo, 1982.

Francia Lorenzo, S. "El cabildo palentino en el siglo XV", Publicaciones de la Institución Tello Téllez de Meneses, 59 (1988), pp. 143-178.

Fuente Pérez, M.J. La ciudad de Palencia en el siglo XV. Aportación al estudio de las ciudades castellanas en la Baja Edad Media, Madrid, 1989.

García Larragueta, S. Catálogo de los pergaminos de la catedral de Oviedo, Oviedo, 1957.

- Colección de documentos de la catedral de Oviedo, Oviedo, 1962.

García Villada, Z. Catálogo de los códices y documentos de la catedral de León, Madrid, 1919.

Gautier Dalché, J. Historia urbana de León y Castilla en la Edad Media (siglos IX-XIII), Madrid, 1979.

González Arce, J.D. "Los precedentes de la fiscalidad extraordinaria de la monarquía hispana: los pedidos reales en la Castilla al sur del Tajo (siglos XIV y XV)", en Collantes de Terán Sánchez, A. (ed.). Fuentes para el estudio del 
negocio fiscal y financiero en los reinos hispánicos (siglos XIV-XVI), Madrid, 2010, pp. 11-40.

González González, R. "Construir la identidad pechera: la lucha contra la exención fiscal en Astorga, León y Oviedo durante el siglo XV”, en Solórzano Telechea, J.A., Arízaga Bolumburu, B. y Haemers, J. (eds.). Los grupos populares en la ciudad medieval europea, Logroño, 2014, pp. 523-541.

Guerrero Navarrete, Y. "La fiscalidad como espacio privilegiado de construcción político identitaria urbana: Burgos en la Baja Edad Media", Studia Historica. Historia Medieval, 30 (2012), pp. 43-66.

Herráez Ortega, M.V. "La construcción del templo gótico", en Yarza Luaces, J., Herráez Ortega, M.V. y Boto Varela, G. (eds.). La catedral de León en la Edad Media, León, 2004, pp. 145-176.

Karge, H. "La arquitectura de la catedral de León en el contexto del gótico europeo", en Yarza Luaces, J., Herráez Ortega, M.V. y Boto Varela, G. (eds.). La catedral de León en la Edad Media, León, 2004, pp. 113-144.

Ladero Quesada, M.A. La Hacienda Real de Castilla en el siglo XV, La Laguna, 1973.

—. Fiscalidad y poder real en Castilla (1252-1369), Madrid, 1993.

—. "Las haciendas concejiles en la Corona de Castilla (una visión de conjunto)", en Finanzas y fiscalidad municipal (V Congreso de Estudios Medievales), Ávila, 1997, pp. 7-71.

Martín Fuertes, J.A. El concejo de Astorga (siglos XIII-XVI), León, 1987.

-. Colección documental del Archivo de la Catedral de León, XI (1301-1350), León, 1995.

—. Colección documental del Archivo Municipal de León (1219-1400), León, 1998.

Menjot, D. "L'incidence sociale de la fiscalité directe des Trastamares de Castille au XIV siècle", Historia. Instituciones. Documentos, 5 (1978), pp. 329-371.

Menjot, D. y Collantes de Terán, A. "La génesis de la fiscalidad municipal en Castilla: primeros enfoques”, Revista d'Història Medieval, 7 (1996), pp. 53-80.

Miguel Vigil, C. Colección histórico-diplomática del Ayuntamiento de Oviedo, Oviedo, 1991 (facsímil de la edición de 1889).

Monsalvo Antón, J.M. El sistema político concejil. El ejemplo del señorío medieval de Alba de Tormes y su concejo de villa y tierra, Salamanca, 1988.

—. "Gobierno municipal, poderes urbanos y toma de decisiones en los concejos castellanos bajomedievales (consideraciones a partir de concejos salmantinos y abulenses)" en Las sociedades urbanas en la España medieval. XXIX Semana de Estudios Medievales (Estella, 15-19 julio 2002), Pamplona, 2003, pp. 409-488.

Nieto Soria, J.M. "Los obispos de la diócesis de León en sus relaciones con la monarquía, 1250-1350", Archivos Leoneses. Revista de estudios y documentación de los reinos hispano-occidentales, 74 (1983), pp. 201-262.

—. "La relación de poderes en un señorío eclesiástico de ámbito urbano: Palencia, 1280-1305”, en La ciudad hispánica durante los siglos XIII a XVI, I, Madrid, 1985 , pp. 625-639. 
- Iglesia y poder real en Castilla. El episcopado (1250-1350), Madrid, 1988.

—. Iglesia y génesis del Estado moderno en Castilla (1369-1480), Madrid, 1993.

Nieto Soria, J.M. y Díaz Ibáñez, J. "Élites y Clientelas Eclesiásticas (siglos XIII al $\mathrm{XV}$ ): propuestas metodológicas desde el caso castellano", en Themudo Barata, F. (ed.), Elites e redes clientelares na Idade Média, Lisboa, 2001, pp. 109-139. Polanco Pérez, A. La catedral de Palencia en el siglo XV (1402-1470). Poder y comportamientos sociales a finales de la Edad Media, Palencia, 2008.

Reglero De La Fuente, C. "La iglesia catedral de Palencia en el siglo XIV (13131397): crisis y reformas”, Edad Media. Revista de Historia, 7 (2005-2006), pp. 121-158.

Rodríguez Fernández, J. "El señorío isidoriano de Renueva (León)”, Archivos Leoneses. Revista de estudios y documentación de los reinos hispano-occidentales, 55-56 (1974), pp. 221-261.

Rodríguez Llopis, M. y García Díaz, I. Iglesia y sociedad feudal: el Cabildo de la Catedral de Murcia en la Baja Edad Media, Murcia, 1994.

Romero Martínez, A. Fisco y recaudación. Impuestos directos y sistemas de cobro en la Castilla medieval, Granada, 1999.

Ruiz Asencio, J.M. Colección documental del Archivo de la Catedral de León, IV (1032-1109), León, 1990.

-. Colección documental del Archivo de la Catedral de León, VIII (1230-1269), León, 1993.

Ruiz Asencio, J.M. y Martín Fuertes, J.A. Colección documental del Archivo de la Catedral de León, IX (1269-1300), León, 1994.

Ruiz de la Peña Solar, J.I. “Alfonso Nicolás, burgués de Oviedo y alcalde del rey”, Asturiensia Medievalia, 2 (1975), pp. 113-176.

-. Historia de Asturias, 5: Baja Edad Media, Salinas, 1979.

-. El comercio ovetense en la Edad Media, Oviedo, 1990.

—. "Las ciudades de señorío eclesiástico y los conflictos por el control del gobierno local (1252-1350)", en Iglesia Duarte, J.I. de la (coord.). Conflictos sociales, políticos e intelectuales en la España de los siglos XIV y XV. XIV Semana de Estudios Medievales, Nájera 2003. Logroño, 2004, pp. 113-145.

—. "Las haciendas concejiles en el norte de la Península: el ejemplo ovetense", en Finanzas y fiscalidad municipal (V Congreso de Estudios Medievales), Ávila, 1997, pp. 507-552.

Ruiz de la Peña Solar, J.I. y Beltrán Suárez, S. "Los orígenes del poder episcopal sobre la ciudad de Oviedo en la Edad Media”, En la España Medieval, 30 (2007), pp. 65-90.

- "Señoríos compartidos, señoríos conflictivos. Los obispos y el concejo de Oviedo en la Edad Media”, en Cavero Domínguez, G. (coord.). Iglesia y ciudad. Espacio y poder (siglos VIII-XIII), León, 2011, pp. 137-177.

Santamaría Lancho, M. "El cabildo catedralicio de Segovia como aparato de poder en el sistema político urbano durante el siglo XV", Studia Historica. Historia Medieval, 8 (1990), pp. 47-77. 
Santamarta Luengos, J.M. Señorío y relaciones de poder en León en la Baja Edad Media (Concejo y Cabildo Catedral en el siglo XV), León, 1993.

—. "Fiscalidad regia en León, 1250-1350", Hispania, 208 (2001), pp. 493-520.

Suárez Beltrán, S. El cabildo de la catedral de Oviedo en la Edad Media, Oviedo, 1986.

—. "Clientelas domésticas en Oviedo durante la Edad Media (siglos XIII-XV)", Asturiensia Medievalia, 8 (1995-1996), pp. 341-359.

Val Valdivieso, M.I. del. "Oligarquía versus común (Consecuencias sociopolíticas del triunfo del Regimiento en las ciudades castellanas)", Medievalismo: Boletín de la Sociedad Española de Estudios Medievales, 4 (1994), pp. 41-58.

Velado Graña, B. La catedral de Astorga y su museo. Guía, Astorga, 1991.

Verdés-Pijuan, P. "La contribución eclesiástica a la fiscalidad municipal en Cataluña durante la época bajomedieval", en Morelló Baget, J. (ed.), Financiar el reino terrenal: la contribución de la Iglesia a finales de la Edad Media (siglos XIII-XVI), Barcelona, 2013, pp. 131-168.

Fecha de recepción del artículo: julio de 2014

Fecha de aceptación y versión final: febrero de 2015 
